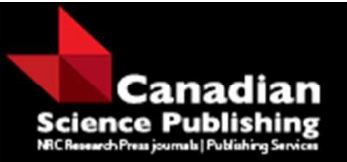

Canadian Journal of Forest Research Revue canadienne de recherche forestière

\title{
Tree species mixing can increase maximum stand density
}

\begin{tabular}{|r|l|}
\hline Journal: & Canadian Journal of Forest Research \\
\hline Manuscript ID & cjfr-2015-0413.R1 \\
\hline Manuscript Type: & Article \\
\hline Date Submitted by the Author: & 14-Dec-2015 \\
\hline Complete List of Authors: & $\begin{array}{l}\text { Pretzsch, Hans; Technische Universität München, Chair for Forest Growth } \\
\text { and Yield Science } \\
\text { Biber, Peter; Technische Universität München }\end{array}$ \\
\hline Keyword: & $\begin{array}{l}\text { maximum stand density, Assmann's yield level, transgressive overdensity, } \\
\text { niche complementarity, canopy and root space filling }\end{array}$ \\
\hline & \\
\hline
\end{tabular}

\section{SCHOLARONE ${ }^{\text {'w }}$}

Manuscripts 


\section{Tree species mixing can increase maximum stand density}

2

3 Hans Pretzsch and Peter Biber

4

5 Corresponding author:

$6 \quad$ H.Pretzsch@1rz.tum.de, Chair for Forest Growth and Yield Science, Technische Universität

7 München, Hans-Carl-von-Carlowitz-Platz 2, 85354 Freising-Weihenstephan, Germany

Abstract:

11 Mixed species stands are on the advance in Europe. They fulfil many functions better than

12 monocultures. Recent papers show mixed stands can have higher yields, but it remains open

13 whether mixed stands simply grow faster along the same self-thinning lines as pure stands, or

14 have higher maximum stand densities

15 We analysed the effect of species mixing on maximum density based on triplets of pure and

16 mixed stands at approximately maximum density. Most considered mixtures include Norway

17 spruce (Picea abies). We show that (i) in mixed stands maximum density is on average by

$18 \quad 16.5 \%$ higher than in neighbouring pure stands, (ii) species mixtures with Norway spruce

19 exceed densities of pure stands by $8.8 \%$ on average. For individual species mixtures, we find

20 a significant density effect of $+29.1 \%$ for Norway spruce mixed with European larch (Larix

21 decidua), and $+35.9 \%$ for Scots pine (Pinus sylvestris) in association with European beech

22 (Fagus sylvatica).

23 No significant links with stand variables like age and mean tree size, and site fertility were 24 found. 
The results indicate that species mixing substantially increases stand density indicating a higher carrying capacity caused by a higher supply and use-efficiency of resources. The implications for inventory, silviculture, and forest modelling are discussed.

Key words: maximum stand density; Assmann's yield level; transgressive overdensity; niche complementarity; canopy and root space filling

\section{Introduction}

The maximum stand density for a tree species on a given site is essential piece of information for assessing site productivity, modelling and predicting stand dynamics, and silvicultural regulation. While site productivity is often characterized by the site index, Assmann (1970, pp 165-172) showed that stands with equal site indexes can vary considerably in maximum stand density depending on the water and nutrients supply. For this phenomenon, he coined the term yield level. For example, assessing the yield level for a given site requires information about the maximum stand density, called the natural stand density by Assmann. Growth models such as yield tables (Assmann 1970, Assmann and Franz 1965), individual tree models (Pretzsch et al. 2002), or eco-physiological growth models (Grote and Pretzsch 2002) often base their predictions of stand density and mortality on species- and site-specific self-thinning lines that are intended to represent maximum stand density. Silvicultural guidelines such as stand density management diagrams (SDMD) often use maximum stand density as an upper boundary and reference line for regulating different density levels (Bégin et al. 2001, Sterba 1975, 1981, Weetman 2005).

For quantifying stand density, the number of trees per unit area $\left(\mathrm{N}, \mathrm{ha}^{-1}\right)$ is ambiguous as the species of interest may differ in current mean tree size and growing area requirement. Stand 
51 basal area $\left(\mathrm{BA}, \mathrm{m}^{2} \mathrm{ha}^{-1}\right)$ is potentially more useful. However, Stand Density Index (SDI, ha $\left.{ }^{-1}\right)$

52 is even more informative since it considers both tree number and size (as does basal area),

53 but is additionally based on allometric theory (Pretzsch 2006, Pretzsch and Biber 2005,

54 Reineke 1933). Reineke (1933) based SDI on the allometric relationship between a given

55 number of trees per ha $\left(\mathrm{N} \mathrm{ha}^{-1}\right)$ and the corresponding quadratic mean diameter in $\mathrm{cm}\left(\mathrm{d}_{\mathrm{q}}\right)$.

56 The standard equation for SDI is SDI $=\mathrm{N} \times\left(25 / d_{q}\right)^{-1.605} \quad[1]$

57 Recently Pretzsch and Schütze (2015) reported maximum SDI values in pure stands of

58 Norway spruce (Picea abies (L.) H. KARST.), Scots pine (Pinus silvestris L.), Douglas-fir

59 (Pseudotsuga menziesii (MIRB.) FrANCO) and European beech (Fagus sylvatica L.).

60 According to their study, intra-specific variation depends mainly on site conditions, indicated

61 by the site index. However, due to the lack of long-term observations in unmanaged and fully

62 stocked stands, quantitative knowledge about maximum stand density is particularly poor for

63 mixed-species stands.

64

65 When information about stand growth and density of mixed species stands is missing, the 66 standard approach is to derive it from pure stands by calculating the weighted mean of e.g. 67 productivity, standing volume or stand density (Río et al. 2015). This is the usual procedure 68 when forest management planning is based on yield table predictions (Kramer and Akça 69 1995, Pretzsch et al. 2015a). However, many recently published works found that mixing 70 may increase stand productivity (Forrester et al. 2006, Piotto 2008, Zhang et al. 2012) as well 71 as stand density (Pretzsch et al. 2015b, see also Reyes-Hernandez and Comeau 2013). 72 Several studies address the stand density issue in mixed stands from a conceptual or a 73 methodological perspective. For quantifying stand density in mixed stands additional stand 74 characteristics such as the skewness of the diameter distribution (Sterba and Monserud 1993) 75 or specific wood density (Woodall et al. 2005) might be used. 
Figure 1 shows a schematic representation of hypotheses of the effect of mixing on maximum stand density based on the $\ln (\mathrm{N})-\ln \left(\mathrm{d}_{\mathrm{q}}\right)$ relationship. Note, that we show just the main part of the $\ln (\mathrm{N})-\ln \left(\mathrm{d}_{\mathrm{q}}\right)$ line where its slope only varies slightly around $\alpha \cong-1.6$. This excludes the early development stages before a stand has fully closed and the very late stages with constant final yield (Körner 2002, Oliver and Larson 1996).

The dashed lines in Figure 1, a-c, represent the weighted mean of the maximum stand densities of the respective pure stands, i.e. the maximum stand density expected under the assumption that the mixed stand behaviour results from nothing more than a linear combination of the pure stands' dynamics. In this case, the $\ln (\mathrm{N})-\ln \left(\mathrm{d}_{\mathrm{q}}\right)$ line observed in a mixed stand would be identical with the expected line, indicating the absence of any true mixing effect in the sense of Forrester and Pretzsch (2015).

Figure 1a assumes that mixing shifts the level of the maximum stand density above $(+)$ or below (-) the expected level; this might be quantified by a modification of the intercept of the $\ln (\mathrm{N})-\ln \left(\mathrm{d}_{\mathrm{q}}\right)$ line. For example, mixing species that are complementary in terms of light ecology can cause an increase (+), whereas a strong niche overlap may reduce the intercept (). Figure $1 \mathrm{~b}$ shows possible resulting patterns, when the positive or negative mixing effect on stand density is negligible in the early stand development phase but becomes more pronounced with proceeding stand development. An increasing positive density effect may result from progressing morphological adaptation to the inter-specific competition, accumulation of nutrient stocks or an enhanced water storage capacity. A continuous negative density effect might result e.g. from decreasing nutrient supply if both species contribute to soil acidification or podsolization (Heinsdorf 1999). Figure 1c shows a combination of both effects displayed in Figures $1 \mathrm{a}$ and $1 \mathrm{~b}$.

Any such deviation from the linear combination of the the pure stands (dashed line in Figure 1) means that the mixed stands can carry more $(+)$ or fewer $(-)$ trees of a given size per unit area. This would indicate emergent properties due to species mixing and a true mixing effect 
103 with significant consequences for production ecology, prognosis, and silviculture. For the

104 purpose of clarity we assumed straight $\ln (\mathrm{N})-\ln \left(\mathrm{d}_{\mathrm{q}}\right)$ lines in Figure 1, however, this is not a

105 pre-condition for such comparisons.

106

107 In this study we examined nine two-species mixtures, five of them including Norway spruce,

108 by compiling a set of unthinned or just slightly thinned research plots in mixed and pure

109 stands. This analysis aspires to answer the following questions:

110 (i) Does the maximum density of mixed stands in general and the maximum density of 111 mixtures including Norway spruce in particular differ from the weighted mean density of 112 neighbouring pure stands?

113 (ii) How does the relationship between maximum stand densities of mixed and pure stands 114 depend on the ecological complementarity of the species assemblages?

115 (iii) Does the relationship between maximum stand densities of mixed and pure stands depend 116 on stand characteristics such as site conditions and stand development phase?

117

118

119

120

121

122

\section{Material and Methods}

\subsection{Material}

The study is based on research plot triplets each comprising two pure stands and one mixed stand, all even-aged and virtually mono-layered. The research plots which were used to compile the triplets come from two different sources. One is the network of long-term experimental plots in Southern Germany, the other is a set of temporary plots, most of them established by members of the COST Action FP1206 EuMIXFOR (see webpage

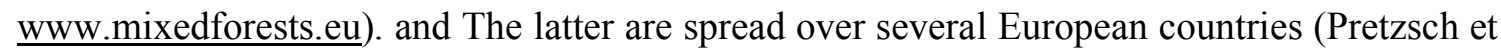
al. 2015b). Plot sizes range between 0.6 and 0.05 ha. 
129 In order to understand the data structure and the statistical procedures described below, it is

130 important to know that all research plots are organised in superordinate units, the so-called

131 trials. All plots belonging to one trial are usually in close vicinity to each other and share the

132 same local site and climate conditions. From all trials we selected only unthinned or slightly

133 thinned plots in order to represent conditions at or close to maximum stand density. From the

134 permanent plot network, which is under survey since 1870 (Pretzsch et al. 2014b), we selected

13560 plots from 29 trials, comprising 217 surveys altogether (Table 1). As each plot in the

136 network is completely documented since its establishment, selecting plots and surveys with

137 approximately maximum stand density was a straightforward process.

138 The temporary plots amounted to 156 plots from 37 trials (Table 1 ). These trials are originally

139 designed as plot triplets. 30 of these trials comprise 3 plots, 6 trials comprise 9 and 1 trial

140 comprises 12 plots. Trials with more than 3 plots are designed as artificial time series with

141 triplets at different stand ages. As these plots were surveyed only once, the number of

142 available surveys (156) equals the number of plots. According to the management records all

143 of these plots are located in stands which were not or only slightly thinned in the past decade.

144 When establishing them, selection criteria in the field were absence of stumps and presence of

145 dead standing trees, both indicating approximate maximum stand density. In total, our data

146 material incorporates 373 surveys from 216 plots from 66 trials (Table 1).

147 This collection of plots was the raw material to form the triplets which are the basis of the

148 study at hand. As only in a few cases the permanent trials were pre-designed as triplets, we

149 carefully checked the records in order to form triplets only from plots with comparable site

150 conditions. This resulted in a set of 26 triplets from long-term plots (Table 2). As one such

151 triplet can comprise more than one survey of the contributing research plots, we called these

152 survey-specific combinations builds, which amounted to 87 for the permanent plots.

153 On the temporary plots there is usually only one build per triplet. However, in the case of the

1547 trials representing artificial time series, we treated the whole time series like real time series 
155 from long-term plots, thus defining each such time series as one triplet with several builds.

156 This procedure was more appropriate for the subsequent statistical evaluation (see below)

157 because the plots of such an artificial time series cannot be assumed to be perfectly

158 uncorrelated. It yielded 37 triplets with 52 from the temporary plots (Table 2). We formed 2

159 mixed triplets (with 2 builds) in addition; they are made up from temporary and permanent

160 plots. In total, the triplets amount to 65 with 141 builds altogether (Table 2).

161 Our data cover the coniferous tree species Norway spruce (Picea abies [L.] H. KARST.), silver

162 fir (Abies alba MiLl.), Scots pine (Pinus silvestris L.), European larch (Larix decidua MiLL.),

163 and Douglas-fir (Pseudotsuga menziesii [MIRB.] FrANCO), and the deciduous species

164 European beech (Fagus sylvatica L.), sessile oak (Quercus petraea [MATT.] LIEBL.), and

165 black alder (Alnus glutinosa [L.] GAERTN.).

166 The nine species combinations covered by our triplets are Norway spruce - silver fir (called

167 "spruce-fir" in the further text for better readability), Norway spruce - Scots pine ("spruce-

168 pine”), Norway spruce - European larch (“spruce-larch”), Norway-spruce - European beech

169 (“spruce-beech”), Norway spruce - black alder (“spruce-alder”), Scots pine - European beech

170 ("pine-beech"), European larch - European beech ("larch-beech"), European beech - sessile

171 oak ("beech-oak"), European beech - Douglas-fir ("beech-douglas”). Best represented are

172 spruce-beech with 15 triplets containing 52 builds, pine-beech (17 triplets, 17 builds), beech-

173 oak (5 triplets, 24 builds), and beech-douglas with 8 triplets and 19 builds (Table 3).

174 In general, as we were careful to form and only triplets with all plots having similar site 175 conditions, the total resulting number of 65 triplets was rather low. However, as such sets of 176 unthinned or just slightly thinned, fully stocked pure and mixed stands are rather rare to our 177 knowledge, we think they form a unique dataset for our questions of interest..

178 The triplets are concentrated in Southern Germany but also include other parts of Central 179 Europe. They range from $-3.172^{\circ}$ to $23.351^{\circ}$ E-longitude, and from $41.895^{\circ}$ to $56.153^{\circ} \mathrm{N}$ 180 latitude. Their elevation range is 20 and $1715 \mathrm{~m}$ a.s.1., mean annual temperature ranges from 
1814.0 to $10.5{ }^{\circ} \mathrm{C}$, and the annual precipitation amounts to $552-2400 \mathrm{~mm} \mathrm{a}^{-1}$, the length of the 182 growing season, defined as the number of days per year with a mean temperature of $10^{\circ}$ and 183 more, is between 151-213 $\mathrm{da}^{-1}$ (Table 4). Table 4 also breaks this information down to the 184 single species combinations where it becomes evident that the mixture pine-beech covers by 185 far the widest geographic and climatic gradient. Most frequently, the soils are brown soils and 186 para-brown soils originating from loess, loam, or sandy loam. The rather broad range of site 187 conditions is also represented by the site index, according to appropriate yield tables from the 188 compilation by Schober (1975). For the purpose of this study, we defined the site index as the 189 mean stand height to be expected according to the yield table at an age of 80 years. For the 190 pure stands, where the site index is not possibly influenced by mixing effects, its value ranges 191 between $12.4 \mathrm{~m}$ in a European larch stand in the Alps and $52.9 \mathrm{~m}$ in a Douglas-fir stand on a 192 fertile lowland site (Table 5). Stand ages cover a range between 25 and 214 years, stem 193 numbers per ha, basal area, and standing volume in pure stands range from 58-5000 ha ${ }^{-1}, 8.0$ -

$194113.7 \mathrm{~m}^{2} \cdot \mathrm{ha}^{-1}$, and $35-2071 \mathrm{~m}^{3} \mathrm{ha}^{-1}$, respectively (Table 5). Note, that in Table 5, which 195 displays this information for each species combination, standing volumes and other area196 related stand characteristics for mixed stands refer to one hectare of the total mixed stand and 197 not to each species' share of the area.

2.2 Methods

201 Although this study deals with two species mixtures, the following methods can be applied 202 analogously to associations of an arbitrary number of species. As our method for quantifying 203 stand density is based on the SDI which uses the tree number and quadratic mean diameter of 204 each involved tree species, the methods are restricted to more or less even-aged cohorts. The 205 reason being that the mean diameter is informative only for roughly unimodal diameter 206 distributions. 
Extending the SDI concept to mixed stands

210 As argued in the introduction, the most informative method for quantifying stand density is 211 the Stand Density Index SDI as it considers both tree number and size and is based on 212 allometric theory (Pretzsch 2006, Pretzsch and Biber 2005, Reineke 1933). However for 213 making SDI-values of different species comparable, their specific growing area requirement 214 must be taken into account. Consider two tree species, whose maximum stand densities $215\left(S D I M A X_{1}, S D I M A X_{2}\right)$ are known from observations of unmanaged, fully stocked pure 216 stands. This information can be used to calculate equivalence coefficients $217 e_{2 \Rightarrow 1}=S D I M A X_{1} / S D I M A X_{2}$

218 or

$219 e_{1 \Rightarrow 2}=S D I M A X_{2} / S D I M A X_{1}$

220 which allow for converting an SDI value of one species into the one of an arbitrarily chosen 221 reference species. Assume we have observed $S D I_{1}$ in a stand of species 1 . If species 2 is the 222 reference species, the conversion into an equivalent SDI is straightforward: $223 S D I_{1 \Rightarrow 2}=S D I_{1} \cdot e_{1 \Rightarrow 2}$

224 Analogously, if species 1 is the reference species and we have measured $S D I_{2}$ in a stand of 225 species 2 , the conversion is

$226 S D I_{2 \Rightarrow 1}=S D I_{2} \cdot e_{2 \Rightarrow 1}$

227 (Río et al. 2015). As our data cover fully stocked stands of nine different Central European 228 tree species, we used the species specific median SDIMAX for calculating general 229 equivalence coefficients which are presented in Table 6. Although we didn't need to use these 230 generic coefficients in the study at hand (see below), we provide them here as they might be 231 useful for some readers in their work. Species specific growing area requirements become 
232 evident in this overview. For example almost all equivalence coefficients for converting

233 Douglas-fir SDIs into other species are considerably below one, while they are very high for

234 sessile oak, often even greater than 2 (Table 6).

235

236 Eliminating species specific growing space requirements from the SDI as shown above is not

237 only a key to species-independent stand density comparisons, but also to calculating the area 238 proportions of the different species in a mixed stand (Dirnberger \& Sterba 2014, Huber et al.

239 2014, Sterba et al. 2014). While the equivalence coefficients given in Table 6 are useful in

240 this context if no pure stands at maximum density are available, our data allowed us an even

241 more precise approach. As the analysis at hand is based on complete triplets in stands close to

242 maximum density, we were able to calculate and to apply specific equivalence coefficients for

243 each build of each triplet. Let, for a given build of such a triplet, SDIMAX $X_{1,2}$ be the SDI of a

244 mixed stand of species 1 and 2, converted to reference species 1. Consequently, if

$245 \operatorname{SDIMAX}_{1,(2)}$ and SDIMAX $X_{(1), 2}$ are the SDIs of species 1 and species 2, respectively, in the

246 mixed stand, SDIMAX $X_{1,2}$ results from

$\operatorname{SDIMAX}_{1,2}=\operatorname{SDIMAX}_{1,(2)}+\operatorname{SDIMAX}_{(1), 2} \cdot \operatorname{SDIMAX}_{1} / \operatorname{SDIMAX}_{2}$

248 with $S D I M A X_{1}$ and SDIMAX 2 being the species-specific SDIs from both pure stands from

249 the same build in the same triplet. This enables us to calculate meaningful mixing proportions

$250 m_{1}$ and $m_{2}$ for species 1 and species 2, respectively, in the mixed stand:

$251 m_{1}=\operatorname{SDIMAX}_{1,(2)} / \operatorname{SDIMAX} X_{1,2}$

$252 m_{2}=\operatorname{SDIMAX}_{(1), 2} \cdot \operatorname{SDIMAX} X_{1} / \operatorname{SDIMAX}_{2} / \operatorname{SDIMAX}_{1,2}$

253 Obviously, chosing species 2 as the reference species would result in the same values for $m_{1}$ 254 and $m_{2}$. 
256 These mixing proportions enable us to calculate $\hat{S} D I_{1,2}$, which is the mixed stand's $S D I$ that 257 would be expected if, biologically, the mixed stand's density would be a mere proportional 258 combination, i.e. a weighted sum of both pure stand densities $S D I_{1}$ and $S D I_{2}$ :

$259 \hat{S} D I_{1,2}=m_{1} \times S D I_{1}+m_{2} \times S D I_{2}$

260 This expected $\hat{S} D I_{1,2}$ can be compared to the actual mixed stand's density $S D I_{1,2}$. If $S D I_{1,2}$ 261 significantly deviates from $\hat{S} D I_{1,2}$, we identify the density effect as an emergent property of 262 the mixture, whereby $\mathrm{SDI}_{1,2}>\hat{\mathrm{SDI}}_{1,2}$ and $\mathrm{SDI}_{1,2}<\mathrm{SDI}_{1,2}$ indicate a density-increasing and a 263 density-lowering mixture effect, respectively.

Quantifying site quality

266

267 A species-specific site index, which is the most straightforward measure of site quality, was 268 obtained by applying appropriate yield tables from the compilation of Schober (1975). For the 269 purpose of this study we defined the site index as the mean stand height at the age of 80 years 270 given by the yield table as a function of the actual mean stand height and age. The reference 271 age of 80 was chosen because, considering the whole data material, this required the least 272 number of extrapolations beyond recorded stand ages.

273 This site index is a good integrative measure for comparing site quality as long as there is 274 only one species involved. An interspecific comparison is problematic, because tree species 275 differ considerably in their typical site-dependent age-height relationship. In order to 276 overcome this difficulty, we designed a standardized site index SISDT which is centered 277 around a value of 1, which in turn should indicate typical site conditions for the species of 278 interest. Values greater and smaller than 1 indicate better and inferior site conditions, 279 respectively. For obtaining SISDT, we first calculated the species-wise median of the site 
280 index at age 80 of each pure stand. Mixed stands were excluded, because due to mixing

281 effects the explanatory power of the site index may be compromised. By dividing each actual

282 site index by the corresponding species' median, we obtained SISDT . For expressing the site

283 quality on the level of a given build of a given triplet, we took the average SISDT of both 284 pure stands.

285 Besides the site index and deduced information like SISDT, other more direct data about site 286 conditions were available for all triplets. Most important were mean annual temperature $T$ $287\left({ }^{\circ} \mathrm{C}\right)$ and precipitation $P(\mathrm{~mm} / \mathrm{a})$ for which records of the last three decades were available.. 288 This made it possible to calculate the aridity index $M$ after de Martonne (1926) which results 289 from

$290 \quad M=P /(T+10)$

291 The higher the Martonne index, the better the water supply for plant growth; the lower this 292 index, the stronger the likelihood of drought. This index has been widely used in recent 293 studies to describe the drought condition or aridity in a given region (Quan et al. 2013). As a 294 recent study by Pretzsch et al. (2014a) shows, the length of the annual growing season $L G S$, 295 defined as the number of days per year with a mean temperature $>10^{\circ} \mathrm{C}$, is another key 296 driving force for forest growth. We were able to estimate LGS for each plot in each triplet 297 using

$298 L G S=343.2-2.5268 \cdot$ latitude $-0.5312 \cdot$ longitude $-0.0402 \cdot$ altitude

299 (Rötzer and Chmielewski 2001) with latitude and longitude being northern latitude und 300 eastern longitude in degrees, and altitude being the plot's elevation above sea level. 
304 All statistical evaluations in this paper ask for systematic density deviations between mixed 305 and pure forest stands. All of them can be integrated into one general linear mixed regression 306 model structure:

307

308

309

$\operatorname{DENSR}_{i j}=\beta_{0}+\beta_{1} \cdot X_{1 i j}+\ldots+\beta_{n i j} \cdot X_{n i j}+t r_{i}+p a_{k}+p a_{k l}+p b_{p}+p b_{p q}+m_{s}+m_{s t}+\varepsilon_{i j}$

310

311 DENSR is a variable that compares the actual density of a mixed stand in a triplet with the

312 mixed stand density that would be expected from the mere combination of both pure stands.

313 We calculated it as

$314 \quad$ DENSR $=\frac{S D I_{1,2}}{\hat{S} D I_{1,2}}-1$

$315 D E N S R$ can be meaningfully tested against zero, where a value greater or smaller than zero

316 indicates a higher density in mixed stands or in pure stands, respectively. The variables

$317 X_{1}, \ldots, X_{n}$ are explanatory variables like site index, water supply, mean annual temperature,

318 precipitation, length of the growing season, and de Martonne's aridity index, or indicators for

319 a stand's development stage like age, height, and mean diameter. Thus, the variables

$320 \beta_{0}, \beta_{1}, \ldots, \beta_{n}$ are the fixed effects parameters. The indexes $i$ and $j$ represent a triplet and a 321 build inside a triplet.

322 The random effect structure of the model is somewhat complicated because in order to 323 account for the data structure having several builds inside many triplets. As each build inside 324 a triplet represents another temporal realization of the superordinate triplet, we introduced a 325 random effect on triplet level in order to cover the correlation among the builds inside a given 326 triplet. This also accounts for the few triplets formed from artificial time series, where the 327 builds cannot be assumed to be fully uncorrelated. In addition there are, in some rare cases, 328 overlaps between different triplets, i.e. two triplets might share one of the contributing stands. 
329 This possible correlation was taken into account by including random effects connected to the

330 trials and plots contributing to a triplet. In detail, $t r_{i} \sim N\left(0, \tau_{1}^{2}\right)$, is the random effect on triplet

331 level. Random effects concerning the first pure stand of a triplet are $p a_{k} \sim N\left(0, \tau_{2}^{2}\right)$ on trial

332 level, and $p a_{k l} \sim N\left(0, \tau_{3}^{2}\right)$ on plot-in-trial level. Analogously, $p b_{p} \sim N\left(0, \tau_{4}^{2}\right)$ and

$333 p b_{p q} \sim N\left(0, \tau_{5}^{2}\right)$ represent trial and plot-in-trial level for the second pure stand. Note that for

334 all triplets covering a given species combination the pure stands of the same species were

335 always coded as the first and the second pure stand, e.g. for the mixture of spruce and beech

336 the pure spruce stands were always pure stand \#1 and the pure beech stands were always pure

337 stand \#2. Finally, $m_{s} \sim N\left(0, \tau_{6}^{2}\right)$ and $m_{s t} \sim N\left(0, \tau_{7}^{2}\right)$ represent trial and plot-in-trial level for a

338 given triplet's mixed stand. The i.i.d residual errors are denoted as $\varepsilon_{i j}$.

339 When fitting the model, there was no case when the full set of these random effects needed to

340 be kept. The decision about which random effects were omitted was made by AIC

341 comparisons in every single case.

342 Note that for research questions $\mathrm{i}$ and ii, as formulated in the introduction, no explanatory

343 variables $X$ were included into the model. Thus, the estimate and the significance of the

344 intercept $\beta_{0}$ tell us directly if a mixed stand effect can be statistically confirmed and how

345 strong it is. E.g. $\beta_{0}=0.10$ and $\beta_{0}=-0.15$ and would indicate an expectation of $10 \%$ higher

346 and 15\% lower stand density in mixed stands compared to pure stands, respectively.

347 For all evaluations we used the statistical software R (R Core Team 2015), especially the

348 packages lme4 (Bates et al. 2014) and lmerTest (Kuznetsova et al. 2015). More details about

349 mixed models can be taken from Zuur et al. (2009).

350

351

3523 Results 
354 Figure 2 shows for all species combinations (top left) and for the nine species assemblages 355 separately how the observed SDI of the mixed stands (ordinate) deviates from the expected $356 S D I$ (abscissa) that results from the area-proportion weighted $S D I$-sum of both pure stands in 357 each triplet. The most frequent species association in our data is Norway spruce - European 358 beech with $\mathrm{n}=52$, followed by the association European beech - sessile/pedunculate oak with $359 \mathrm{n}=24$ (see also Table 5). The mixtures spruce-alder $(\mathrm{n}=3)$ and larch-beech $(\mathrm{n}=1)$ are 360 hardly represented in our data. Although they cannot be meaningfully analysed for 361 themselves, we included them in our overarching analyses. For almost all mixtures the point 362 cloud's center of gravity is located above the bisector line, i.e., it suggests that, on average, 363 stand density tends to be higher in mixed compared with pure stands. Species with strong 364 complementary in light ecology such as the combination of spruce-pine, spruce-larch, and 365 pine-beech seem to result in higher over-density compared with combinations of ecologically 366 more similar species.

367

368 Before we continue with describing the statistical results in detail we would like to point out 369 that the fit results of each regression model (according to Equation 1) we present in this study 370 are compiled in Table 7. From a technical point of view it is interesting to see that the random 371 effects common to most models were connected with the mixed stand in each triplet on trial 372 level and on plot level (random effects $m_{s}$ and $m_{s t}$ in Equation 12). Only in a few cases do

373 we observe noteworthy random variation with the first pure stand in a triplet $\left(p a_{k}, p a_{k l}\right.$ in

374 Equation 12) at the triplet level itself $\left(t r_{i}\right)$. In no case was the inclusion of random effects due

375 to the second pure stand $\left(p b_{p}, p b_{p q}\right)$ necessary. 
377 3.1 Mixture effect on stand density in general and for species associations with Norway

378 spruce

379

380 In order to test for significant $S D I$ devations in mixed from pure stands (research question i)

381 we used the statistical model according to Equation 12 without including any explanatory

382 variable $\mathrm{X}$. Thus, the estimated value of the parameter $\beta_{0}$ represents the expected relative

383 deviation DENSR (see Equation 13). If $\beta_{0}$ differs significantly from 0 , we can assume a true

384 species mixing effect on stand density at full stocking. Despite a large variance in DENSR,

385 our analyses show that over all species associations there is a mean superiority of the mixed

386 stands amounting to $16.5 \%\left(\beta_{0}=0.165, p<0.001\right.$, Figure 3 left, Table 7$)$. Taking into

387 account only the species associations containing Norway spruce, this superiority is at $8.8 \%$

388 only, but still significant $\left(\beta_{0}=0.088, p<0.05\right.$, Figure 3 right, Table 7$)$.

$390 \quad 3.2$ Mixture effect on stand density for single species associations

391

392 We also fitted the same model separately to the data for each single species association, 393 except for larch-beech, where there was only one observation available. This analysis is

394 related to research question ii. As can be taken from Figure 4, the relative density gain is 395 always greater than zero (without considering larch-beech; note that the spruce-alder result 396 comes from one triplet only); in the cases of spruce-larch and pine-beech it is significantly so 397 with mixture-induced density gains of about $29 \%$ and $36 \%\left(\beta_{0}=0.291, p<0.01\right.$, and $398 \beta_{0}=0.359, p<0.001$, respectively, Table 7). Both significant effects are observed in species 399 associations with a highly shade tolerant species (European beech) or an intermediately shade 400 tolerant species (Norway spruce) mixed with a very light demanding species (European larch, 401 Scots pine). 
403 3.3 Mixture effect on density in connection with stand development and site quality

404

405

406

407

408

409

410

411

412

413

414

415

416

417

418

419

420

421

422

423

426

427

Although we examined several variables describing stand development stage (stand age, mean tree height, mean diameter, dominant height, dominant diameter) as predictor variables $X$ in Equation 12, none of them showed even a weak significant effect on DENSR. Exemplary, we show the non-significant age-effect in Figure 5 (see also Table 7), where stand age as predictor variable was used untransformed for all species mixtures (left) and as its natural logarithm for all mixtures containing Norway spruce (right).

In the same way, we also couldn't detect any significant effect of site quality, regardless whether it was included as a climate variable (precipitation, temperature, aridity index, length of the growing season) or expressed through a site index. In Figure 6 (see also Table 7) we show this by example of a model which used the standardized site index SDISTD (see methods section) for each build of a triplet.

\section{Discussion}

\section{Species mixing as a cause for increased stand density}

Many studies show that tree species mixing can significantly increase the stand productivity in terms of stem volume growth (Forrester et al. 2006, Piotto 2008, Pretzsch et al. 2010, 2013, 2015b, Zhang et al. 2012). In general, the stand volume growth results mainly from height growth (vertical component) and stand basal area growth (horizontal component), while changes of the stem form factor play a minor role as they occur rather slowly (Assmann 1970, p 165-167). Several studies provided evidence that mixing can significantly increase basal 
area growth (Hein and Dhôte 2006, Pretzsch et al. 2015b). For the current state of knowledge about over-yielding in terms of basal area and volume growth in mixed-species stands of Norway spruce and Scots pine, that are also in the focus of this study, see the publication by Drössler et al. (in review) in this special issue.

Our findings show that mixing can also significantly increase the accumulation of remaining stand basal area, which means a reduction of mortality and increase of stand density (Figure 3, cf. Condés \& Río 2015).

According to Pretzsch et al. (2015b), mixing hardly increases height growth or the site index; if one species in a mixed stand is inferior, its height growth may even decrease due to interspecific competition for light (Wiedemann 1951, p 131-133). Thus, while leaving the site index rather unaffected, species mixing can significantly increase stand basal area growth and stand density, which is equivalent with an increase of the yield level as defined by Assmann (1970, p 167).

Height growth and site index are primarily determined by supra-regional environmental conditions (Kahn 1994) like humidity, temperature, length of the growing season, which can hardly be influenced by mixing. Stand basal area growth, stand density and thereby yield level on different sites with the same site index, are mainly determined by the local supply, capture and use efficiency of water and nutrients. Following this line of thought, our results suggest that the local supply, capture and use efficiency of water and nutrients may be strongly modified by species mixing.

Other silvicultural measures such as spacing, thinning, or fertilization mostly accelerate growth but do not increase stand density, as they raise the turn-over, but not the stock of resources (Long et al. 2004). So, the stands develop faster but the tree numbers per unit area at a given mean diameter stay the same. Fertilization may only increase stand density if repeated so often, that the fertilizer is not simply absorbed by the faster growing trees, but can 
453 sustain a higher stock and consequently a higher stand density. Species mixing seems to take

454 effect like a continuous fertilization or irrigation.

455

456

Mixed stand density and niche complementary

457

458 Growth and yield on low growth sites is probably limited by water and nutrient supply, while 459 growth on high growth sites is rather limited by light. Species assemblages with different and 460 complementary structural and functional traits can induce a more complete use both above 461 and below ground resources (Kelty 1992).

462 For the species mixtures with significant over-densities as identified before, Figure 7

463 illustrates this based on the mean diameter-tree number relationship in double logarithmic 464 (left) and linear (right) representation. It can be seen as the empiric counterpart to Figure 1 in 465 terms of how the displayed stem numbers and mean diameters are calculated. For the mixed 466 stands, the stem number is simply the total number of trees per ha, and the mean diameter is 467 the area share weighted mean of both species. For the monospecific stands, stem numbers and 468 mean diameters result from applying the area shares of the corresponding mixed stand (i.e. 469 from the same build in the same triplet) to the stem numbers and mean diameters and which 470 results in a tree number and a mean diameter for a species combination without mixture 471 effects on stand density. Throughout all species assemblages, the self-thinning line of the 472 mixed stands (black) lies above the weighted mean self-thinning line of the two monocultures 473 (grey). The level of the self-thinning line is raised by species mixing whereas the slope 474 remains the same. This underpins that mixing can reduce tree mortality of the total stand so 475 that their self-thinning line can be significantly higher as hypothesized in Figure 1a.

476 Complementarity in spatial or temporal niche occupation and exploitation may be relevant at 477 the very beginning of stand development, and the role of the associated tree species may also 478 change during the ongoing development. For example early-successional pioneer species may 
479 be above late-succession species first, but below them in more advanced stages of stand 480 development.

481 Four species included in this study, Scots pine, European larch, black alder, and sessile oak 482 are light demanding and belong to the early-successional group. European beech and silver fir 483 are shade tolerant late-succession species. Our analyses revealed a strong positive mixture 484 effect for the species association pine-beech which is a classic combination of an early485 successional and a late-successional species (Figure 4). For species assemblages with more 486 similar ecological traits like beech-douglas and spruce-beech we cannot substantiate 487 significant density effects due to mixing (Figure 4).

488 Norway spruce is somehow intermediate concerning growth dynamics, height dominance and 489 shade tolerance. When mixed with light demanding, fast growing but early culminating 490 species, Norway spruce often occupies the lower canopy space in the earlier phases of stand 491 development but enters the upper canopy later. For one of these mixtures, spruce-larch, we 492 can demonstrate a very pronounced positive density effect of mixture, whereas there is a 493 weaker tendency for spruce-pine only, which cannot be corroborated statistically. When 494 mixed with shade tolerant and late culminating species, Norway spruce may be ahead in the 495 first part and be caught up by the admixed species in height growth in the second part. 496 However, for both such mixtures, spruce-fir and spruce-beech, we cannot substantiate a 497 significant density effect.

498 In both types of mixture (with early-successional and late-successional species) Norway 499 spruce increases the vertical structure of the canopy space, either by extending it because of 500 higher shade tolerance in the lower canopy space or by extending it due to faster height 501 growth. Although this could only partly be shown on the level of single species associations, 502 the combined analysis of all associations including Norway spruce reveals an effect which 503 seems plausible given the considerations above: Species assemblages with Norway spruce 504 tend towards positive mixture effects on density but mixtures with this species do not achieve 
505 the high levels of over-density shown for combinations of other complementary species 506 (Figure 3).

507 Niche complementary as described above is not limited to above ground space occupied by a 508 forest stand. Species may also access below ground resources in a complementary way. For 509 example, consider sandy soils impoverished by repeated cultivation of pure Scots pine or 510 Norway spruce stands as described for instance by Heinsdorf (1999) and already Wiedemann 511 (1923). Introducing European beech or other broadleaved species as additional species in such 512 stands is believed to have positive effects on the litter decomposition (Augusto et al. 2002), 513 humus type (Block 1997), as well as on soil penetration by roots, nutrient supply and water 514 storage capacity (Rothe 1997). This may finally results in an increase in growth of mixed 515 versus pure stands (Heinsdorf 1999, von Mammen et al. 2003). The stand-level combination

516 of structurally and chemically contrasting litter types may, in the long term, improve fertility 517 and resource storage capacity of soils (carbon, water and nutrients), perhaps mediated through 518 stimulated bioturbation (Augusto et al. 2002, 2015, Heinsdorf 1999, Rothe and Binkley 519 2001).

520

Effect of site conditions and stand age

We expected that over-density would be higher on poor sites and become more distinct with

524 increasing stand age. On poor sites, the benefit of niche complementary in terms of nutrient 525 supply might be stronger than on rich sites. However, we found no significant relationship 526 between site conditions and density effect. With progressing stand development, mixing 527 effects on stand density may result from increasing morphological adaptations to the inter528 specific environment and/or the above-mentioned continuous improvement of the soil

529 fertility. However, we also found no significant change in over-density with progressing stand 530 development (Figures 5, 6). 
531 These results highlight the complexity of species interactions. Competition, complementarity,

532 and facilitation depend on many factors such as stand developmental stage, stand density, and

533 site conditions (Forrester 2014), and possibly also interactions among these factors that

534 require further studies (Pretzsch et al. 2015b) .

535

536

Methodological considerations

537

538 This study is based on permanently and temporally established sets of fully stocked pure and

539 neighbouring mixed-species stands that represent maximum or at least approximately

540 maximum stand density. Such unthinned or just moderately thinned experiments with pure

541 and mixed plots of comparable site conditions are essential for revealing any true effects of

542 tree species mixing on the maximum stand density.

543 Studies based on long-term experiments regulated at different stand density levels below the

544 maximum carrying capacity (e.g. Amoroso and Turnblom 2006, Forrester et al. 2006) provide

545 valuable insight into the relationship between stand density and productivity (cf. Assmann

546 1970, pp 227-235, Pretzsch 2005, Zeide 2001, 2002). However, if mixed-species experiments

547 do not include unthinned and fully stocked treatment variants, they cannot provide evidence

548 of mixing effects on the carrying capacity. i.e. maximum stand density, because the sought-

549 after effects are at least partly "thinned away".

550 Studies based on forest inventory plots (Condés et al. 2013, Vallet and Pérot 2011) may cover

551 a certain portion of fully stocked pure and mixed-species stands. However, if the stand history

552 is unknown, it remains open which plots are really at maximum stand density. If pure and

553 mixed stands differ in site conditions, site and mixing effects may be confounded. In addition,

554 there might also be unknown provenance differences which add to the uncertainties.

555 Using unthinned and just slightly thinned plots of permanently or temporally established

556 experiments, and ensuring comparable site conditions of the combined pure and mixed stands, 
557 and knowing the history of the included stands we were able to exclude the most important 558 confounding factors that might have impaired our results. Especially the maximum densities

559 of the pure stands, which are of critical importance in this study, could be directly taken from 560 each build of each triplet, ensuring avoidance of improper generalisations as far as possible.

561 However, compiling the triplet collection used in this study, especially the post-hoc-triplets,

562 required major effort, but still resulted in unbalanced representations among the different

563 mixture types (cf. Figure 4). The range of site conditions, expressed through site indexes (cf

564 Table 5) is surprisingly broad, at least for the more common species combinations.

565 Nevertheless, overall data supply of comparable pure and mixed stands at or near maximum

566 stand density is only marginally satisfactory.

567

Consequences for research and forest practice

Long-term mixing experiments that include unthinned or just slightly thinned reference plots

571 in mixed and pure stands as well as variants with different density reductions are of rather

572 unique value. Future mixed-species trials should integrate such fully stocked and unmanaged

573 plots as they can reveal the effect of mixing on maximum stand density and stand

574 productivity. The maximum stand density on the fully stocked and unmanaged plots is a

575 useful reference for keeping the thinned plots of such experiments on defined levels of

576 relative density (e.g., 80, 50, $30 \%$ of the maximum density). This can contribute to answering

577 the essential question how any overyielding or underyielding of mixed-species stands

578 compared with monocultures is modified by different thinning grades (Río et al. 2015).

579 In addition to the strengthening of the empirical basis, methodological approaches of

580 quantifying stand density in homogeneous as well as in complex stands (Ducey and Knapp

581 2010; Ducey and Larson 2003), deriving the maximum stand density from experiments and

582 inventory data (Río et al. 2015; Pretzsch et al. 2015b, Sterba 1975), and application of density 
583 measures for regulating the stand density in experiments and forest practice (Bégin et al.

584 2001; Weetman 2005) are essential.

585 Growth models that use the concept of maximum stand density for predicting tree mortality 586 should be complemented by mixture effects as revealed in this study in order to predict 587 plausible stand densities.

589 Knowledge about any increase of maximum stand density by species mixing is relevant for 590 developing useful silvicultural guidelines. If thinning guidelines for mixed stands simply 591 adopt the target curves for stand basal area or tree number developed for pure stands, this may 592 result in suboptimal stand densities and thereby losses in stand productivity.

593

\section{Conclusions}

While a series of recently published works quantified the enhancing effect of mixing on stand 597 productivity, we show that mixing can also increase the maximum stand density compared 598 with pure stands with similar site conditions and stand age. That means that mixed stands can carry more trees of a given size. The increase in maximum density compared with pure stands was significant for the full data set and for tree species combinations with complementary ecological traits, but not for more similar species. This finding suggests that especially in assemblages of complementary species the supply, capture, or use efficiency of resources is increased to such an extent that not only the growth rate but also the carrying capacity is continuously higher than in pure stands. The question, which particular resources become

605 more efficiently used and how this depends on site conditions and stand age requires further 606 research. The finding that neither site conditions nor stand age affected the increase in stand

607 density needs further analyses on the grounds of a broader dataset in terms of site conditions 608 and species combinations. Although the particular causes of over-density need further 
609 clarification, their average of $16.5 \%$ and species-dependent range from 8.8 up to $35.9 \%$ calls

610 for attention and consideration in stand inventories, experimental design, growth modelling, 611 and silvicultural guidelines.

612

\section{Acknowledgement}

614

615 The authors thank Phil Comeau for initiating the special issue at hand and making it possible 616 that this study became part of it. They also thank the German Science Foundation for 617 providing the funds for the projects PR 292/12-1 "Tree and stand-level growth reactions on 618 drought in mixed versus pure forests of Norway spruce and European beech“, the European 619 Union for funding the COST Action FP1206 EuMIXFOR which provided some of the triplet 620 data, the Bavarian State Ministry for Nutrition, Agriculture, and Forestry for permanent 621 support of the project W 07 "Long-term experimental plots for forest growth and yield 622 research“" (\# 7831-22209-2013), and the Bayerische Staatsforsten (BaySF) for supporting the 623 establishment of a part of the plots used in this study. Thanks are also due to Ulrich Kern for 624 the graphical artwork, and to two anonymous reviewers for their constructive criticism.

\section{References}

628

629

630

631

632

633

634

635

636

637

638
Amoroso, M. M., and Turnblom, E. C. 2006. Comparing productivity of pure and mixed Douglas-fir and western hemlock plantations in the Pacific Northwest. Can. J. For. Res. 36(6): 1484-1496.

Assmann, E. 1970. The principles of forest yield study. Pergamon Press, Oxford, New York, $506 \mathrm{p}$.

Assmann, E., and Franz, F. 1965. Vorläufige Fichten-Ertragstafel für Bayern. Forstw. Cbl. 84(1): 13-43. 
639

640

641

642

643

644

645

646

647

648

649

650

651

652

653

654

655

656

657

658

659

660

661

662

663

664

665

666

667

668

669

670

671

672

673

674

675

676

677

678

679

680

681

682

683

Augusto, L., Ranger, J., Binkley, D., and Rothe, A. 2002. Impact of several common tree species of European temperate forests on soil fertility. Ann. For. Sci. 59: 233253.

Augusto, L., de Schrijver, A., Vesterdal, L., Smolander, A., Prescott, C., and Ranger, J. 2015. Influences of evergreen gymnosperm and deciduous angiosperm tree species on the functioning of temperate and boreal forests. Biol. Rev. 90: 444466.

Bates, D., Maechler, M., Bolker, B., and Walker, S. 2014. lme4: Linear mixed-effects models using Eigen and S4_. R package version 1.1-7, <URL: http://CRAN.Rproject.org/package $=1 \mathrm{me} 4>$.

Bégin, E., Bégin, J., Bélanger, L., Rivest, L.-P., and Tremblay, S. 2001. Balsam fir selfthinning relationship and its constancy among different ecological regions. Can. J. For. Res. 31: 950-959.

Block, J. 1997. Disposition rheinland-pfälzischer Waldbodensubstrate gegenüber Versauerung. In: Ministerium für Umwelt und Forsten Rheinland-Pfalz: Waldschäden, Boden- und Wasserversauerung durch Luftschadstoffe in Rheinland-Pfalz, Mainz, pp 16-27.

Condés, S., del Río, M., and Sterba, H. 2013. Mixing effect on volume growth of Fagus sylvatica and Pinus sylvestris is modulated by stand density. For. Ecol. Manage. 292: 86-95.

Condés, S., and del Río, M. 2015. Climate modifies tree interactions in terms of basal area growth and mortality in monospecific and mixed Fagus sylvatica and Pinus sylvestris forests. Eur. J. Forest Res., 134(6): 1095-1108.

Dirnberger, G. F., and Sterba, H. 2014. A comparison of different methods to estimate species proportions by area in mixed stands. Forest Syst. 23(3): 534-546.

Drössler, L., Bielak, K., Dudzinska, M., Mason, W., Pretzsch, H., Wellhausen, W., Liziniewicz, M., Nilsson, U., Valkonen, S., Koricheva, J., Ruohomaki, K., and Agestam, E. (in review). Stand growth in Scots pine-Norway spruce mixed forest experiments in Europe - Temporal changes in over-/underyielding and the differences between sites, Can. J. For. Res., Special Issue Spruce 2015.

Ducey, M. J., and Knapp, R. A. 2010. A stand density index for complex mixed species forests in the northeastern United States. For. Ecol. Manage. 260(9), 1613-1622.

Ducey, M. J., and Larson, B. C. 2003. Is there a correct stand density index? An alternate interpretation. West. J. Appl. For. 18(3), 179-184. 
684

685

686

687

688

689

690

691

692

693

694

695

696

697

698

699

700

701

702

703

704

705

706

707

708

709

710

711

712

713

714

715

716

717

718

719

720

721

722

723

724

725

726

727

728

729

730

731

732

733

Forrester, D. I. 2014. The spatial and temporal dynamics of species interactions in mixed-species forests: From pattern to process. For. Ecol. Manage. 312: 282-292.

Forrester, D. I., and Pretzsch, H. 2015. On the strength of evidence when comparing ecosystem functions of mixtures with monocultures, A Tamm Review, For. Ecol. Manage. 356: 41-53.

Forrester, D. I., Bauhus, J., Cowie, A. L., and Vanclay, J. K. 2006. Mixed-species plantations of Eucalyptus with nitrogen-fixing trees: A review, For. Ecol. Manage. 233: 211-230.

Grote, R., and Pretzsch, H. 2002. A model for individual tree development based on physiological processes. Plant Biol. 4: 167-180.

Hein, S., Dhôte, J. F. 2006. Effect of species composition, stand density and site index on the basal area increment of oak trees (Quercus sp) in mixed stands with beech (Fagus sylvatica L) in northern France. Ann. For. Sci. 63:457-467.

Heinsdorf, D. 1999. Das Revier Sauen - Ein Beispiel für erfolgreichen Waldumbau, Schriftenreihe des Ministeriums für Ernährung, Landwirtschaft und Forsten, Eberswalder Forstliche Schriftenreihe, Landesforstanstalt Eberswalde, Ministerium für Ernährung, Landwirtschaft und Forsten, Brandenburg, Band VI, $30 \mathrm{p}$.

Huber, M. O., Sterba, H., and Bernhard, L. 2014. Site conditions and definition of compositional proportion modify mixture effects in Picea abies - Abies alba stands. Can. J. For. Res. 44(10): 1281-1291

Kahn, M. 1994. Modellierung der Höhenentwicklung ausgewählter Baumarten in Abhängigkeit vom Standort. Forstliche Forschungsberichte München 141, 221 p.

Kelty, M. J. 1992. Comparative productivity of monocultures and mixed stands. In: Kelty, MJ, Larson BC, Oliver CD (eds.): The ecology and silviculture of mixed-species forests. Kluwer, Dordrecht, 125-141.

Körner, C. 2002. Ökologie. In: Sitte P, Weiler EW, Kadereit JW, Bresinsky A, Körner C (eds) Strasburger Lehrbuch für Botanik, $35^{\text {th }}$ edn. Spektrum Akademischer Verlag, Heidelberg, Berlin, pp 886-1043.

Kramer, H., and Akça, A. 1995. Leitfaden zur Waldmeßlehre. JD Sauerländer's Verlag, Frankfurt am Main, $266 \mathrm{p}$.

Kuznetsova, A., Brockhoff, P. B., and Bojesen Christensen, R. H. 2015. lmerTest: Tests in Linear Mixed Effects Models. $\mathrm{R}$ package version 2.0-25. http://CRAN.Rproject.org/package $=$ lmerTest.

Long, J. N., Dean, T. J., and Roberts, S. D. 2004. Linkages between silviculture and ecology: examination of several important conceptual models, For. Ecol. Manage. 200: 249-261. 
734

735

736

737

738

739

740

741

742

743

744

745

746

747

748

749

750

751

752

753

754

755

756

757

758

759

760

761

762

763

764

765

766

767

768

769

770

771

772

773

774

775

776

777

778

779

780

781

782

783

von Mammen, A., Bachmann, M., Prietzel, J., Pretzsch, H., and Rehfuess, K. E. 2003. Bodenzustand, Ernährungszustand und Wachstum von Fichten (Picea abies Karst.) auf Probeflächen des Friedenfelser Verfahrens in der Oberpfalz, Forstw. Cbl., 122: 99-114.

de Martonne, E. 1926. Une novelle fonction climatologique: L'indice d'aridité. La Météorologie 21: 449-458.

Oliver, C. D., and Larson, B. 1996. Forest Stand Dynamics, John Wiley \& Sons Inc, New York, Chichester, Brisbane, Toronto, Singapore, $520 \mathrm{p}$.

Piotto, D. 2008. A meta-analysis comparing tree growth in monocultures and mixed plantations. For. Ecol. Manage. 255(3): 781-786.

Pretzsch, H., Biber, P., Durský, J. 2002. The single tree based stand simulator SILVA. Construction, application and evaluation. For. Ecol. Manage. 162: 3-21.

Pretzsch, H., Biber, P., Schütze, G., Uhl, E., and Rötzer, Th.2014a. Forest stand growth dynamics in Central Europe have accelerated since 1870. Nat. Commun. 5: $10.1038 /$ ncomms5967.

Pretzsch, H., and Biber, P. 2005. A re-evaluation of Reineke's rule and Stand Density Index. For. Sci. 51: 304-320.

Pretzsch, H., Uhl, E., Nickel, M., Steinacker, L., and Schütze, G. 2014b. Die lange Geschichte der ertragskundlichen Versuchsflächen in Bayern. LWF Wissen 76: 7-30.

Pretzsch, H., Block, J., Dieler, J., Dong, P. H., Kohnle, U., Nagel, J., Spellmann, H., and Zingg, A. 2010. Comparison between the productivity of pure and mixed stands of Norway spruce and European beech along an ecological gradient. Ann. For. Sci. 67: DOI:10.1051/forest/2010037.

Pretzsch, H., Bielak, K., Block, J., Bruchwald, A., Dieler, J., Ehrhart, H.-P., Kohnle, U., Nagel, J., Spellmann, H., Zasada, M., and Zingg, A. 2013.Productivity of pure versus mixed stands of oak (Quercus petraea (MATT.) LIEBL. and Quercus robur L.) and European beech (Fagus sylvatica L.) along an ecological gradient. Eur. J. For. Res. 132(2): 263-280.

Pretzsch, H. 2006. Species-specific allometric scaling under self-thinning. Evidence from long-tern plots in forest stands. Oecologia 146: 572-583.

Pretzsch, H., Forrester. D. I., and Rötzer, Th. 2015a. Representation of species mixing in forest growth models. A review and perspective. Ecol. Model. 313: 276-292.

Pretzsch, H., del Río, M., Ammer, Ch., Avdagic, A., Barbeito, I., Bielak, K., Brazaitis, G., Coll, L. , Dirnberger, G., Drössler, L., Fabrika, M., Forrester, D. I., Godvod, K., Heym, M., Hurt, V., Kurylyak, V., Löf, M., Lombardi, F., Matović, B., Mohren, F., Motta R, den Ouden J, Pach M, Ponette Q, Schütze G, Schweig J, Skrzyszewski J, Sramek, V., Sterba, H., Stojanović, D., Svoboda, M., Vanhellemont, M., Verheyen, K., Wellhausen, K., Zlatanov, T., and Bravo-Oviedo, A. 2015b. Growth and yield of mixed versus pure 
784

785

786

787

788

789

790

791

792

793

794

795

796

797

798

799

800

801

802

803

804

805

806

807

808

809

810

811

812

813

814

815

816

817

818

819

820

821

822

823

824

825

826

827

828

829

830

831

832

833

stands of Scots pine (Pinus sylvestris L.) and European beech (Fagus sylvatica L.) analysed along a productivity gradient through Europe. Eur. J. Forest Res. 134(5): 927947, DOI 10.1007/s10342-015-0900-4.

Pretzsch, H., and Schütze, G. 2015. Ernst Assmann review: Effect of tree species mixing on the size structure, density, and yield of forest stands, Eur. J. Forest Res., DOI 10.1007/s10342-015-0913-z.

Quan, C., Han, S., Utescher, T., Zhang, C., Liu, Y. S. 2013. Validation of temperatureprecipitation based aridity index: paleoclimatic implications. Palaeogeogr. Palaeocl. 386: 86-95.

R Core Team 2015. R: A language and environment for statistical computing. R Foundation for Statistical Computing, Vienna, Austria. URL http://www.R-project.org/.

Reineke, L. H. 1933. Perfecting a stand-density index for even-aged forests. J. Agr. Res. 46: 627-638.

Reyes-Hernandez, V., Comeau, P. G., and Bokalo, M. 2013. Static and dynamic maximum size-density relationships for mixed trembling aspen and white spruce stands in western Canada, For. Ecol. Manage. 289: 300-311

Río M., Pretzsch H., Alberdi I., Bielak K., Bravo, F., Brunner A., Condés S., Ducey M.J., Fonseca T., von Lüpke N., Pach M., Peric S., Perot T., Souidi Z., Spathelf P., Sterba H., Tijardovic M., Tomé M., Vallet P., and Bravo-Oviedo A. 2015. Characterization of the structure, dynamics, and productivity of mixed-species stands: Review and perspectives. Eur. J. Forest Res., DOI: 10.1007/s10342-015-0927-6

Rötzer, Th., and Chmielewski, F. 2001. Phenological maps of Europe. Clim. Res., 18: 249257.

Rothe, A. 1997. Einfluß des Baumartenanteils auf Durchwurzelung, Wasserhaushalt, Stoffhaushalt und Zuwachsleistung eines Fichten-Buchen-Mischbestandes am Standort Höglwald. Forstliche Forschungsberichte München 163, 174 p.

Rothe, A., and Binkley, D. 2001. Nutritional interactions in mixed species forests: a synthesis. Can. J. For. Res.31: 1855-1870.

Schober, R. 1975. Ertragstafeln wichtiger Baumarten. JD Sauerländer's Verlag, Frankfurt am Main.

Sterba, H., and Monserud, R. A. 1993. The maximum density concept applied to uneven-aged mixed stands. For. Sci. 39: 432-452.

Sterba, H. 1975. Assmanns Theorie der Grundflächenhaltung und die „Competition-DensityRule“ der Japaner Kira, Ando und Tadaki. Cbl. für das ges. Forstwesen, 92 (1): 46-62.

Sterba, H. 1981. Natürlicher Bestockungsgrad und Reinekes SDI. Cbl. für das ges. Forstwesen 98: 101-116. 
834

835

836

837

838

839

840

841

842

843

844

845

846

847

848

849

850

851

852

853

854

855

856

857

858

859

860

861

862

863

864

865

866

867

868

869
Sterba, H, del Río, M., Brunner, A., and Condés, S. 2014. Effect of species proportion definition on the evaluation of growth in pure vs. mixed stands. Forest Syst., 23(3): 547559.

Vallet, P., and Pérot, T. 2011. Silver fir stand productivity is enhanced when mixed with Norway spruce: evidence based on large-scale inventory data and a generic modelling approach. J. Veg. Sci., 22(5): 932-942.

Weetman, G. 2005. Partial cutting in the boreal: Some concerns, its history and its place in management, Lecture on workshop "Partial cutting in the eastern boreal forest: current knowledge and perspectives". Univ of Quebéc at Temiskaming UQAT, Rouyn-Noranda, revised and updated Jan/05, UBC Vancouver, $29 \mathrm{p}$.

Wiedemann, E. 1923. Zuwachsrückgang und Wuchsstockungen der Fichte in den mittleren und unteren Höhenlagen der sächsischen Staatsforsten. Kommissionsverlag W Laux, Tharandt, $181 \mathrm{p}$

Wiedemann, E. 1951. Ertragskundliche und waldbauliche Grundlagen der Forstwirtschaft. JD Sauerländer's Verlag, Frankfurt am Main, 346 p.

Woodall, Ch. W., Miles, P. D., and Visassage, J. S. 2005. Determining maximum stand density in mixed species stands for strategic-scale stocking assessments, For. Ecol. Manage. 216: 367-377.

Zeide, B. 2001. Thinning and growth: A full turnaround. J. Forestry 99: 20-25.

Zeide, B. 2002. Density and the growth of even-aged stands. For. Sci. 48: 743-754.

Zhang, Y., Chen, H. Y. H., and Reich, P. B. 2012. Forest productivity increases with evenness, species richness and trait variation: a global meta-analysis. J. Ecol. 100(3): 742-749.

Zuur, A. F., Ieno, E. N., Walker, N. J., Saveliev, A. A., and Smith, G. M. 2009. Mixed Effects Models and Extensions in Ecology with R. Springer. 574 p. 


\section{Captions of figures and tables}

872

873 Figure 1: Hypotheses on the effect of mixing on the maximum stand density in schematic 874 representation based on the $\ln (\mathrm{N})-\ln (\mathrm{dq})$ relationship. The broken line represents the 875 weighted mean of the maximum stand densities of the respective pure stands, i.e. the 876 maximum stand density expected under the assumption that the mixed stand behaviour is the 877 linear combination of the pure stands. Compared with this expected maximum stand density 878 the observed maximum density of the mixed stands may deviate in (a) the level of the $\ln (n)$ $879 \ln (d)$ line, i. e., in its intercept, (b) the decline of density with increasing mean size, i. e., the 880 slope of the $\ln (n)-\ln (d)$ line, or (c) both the modification of intercept and slope on the $\ln (n)-$ 881 $\ln (\mathrm{d})$ line.

882

883

Figure 2: Observed SDI in the mixed stands (SDI mixed) vs. expected SDI (SDI mono) from 885 combining the monospecific (= pure) stands of a triplet. Each grey circle represents one build 886 of a triplet. The black dots show the point clouds' centers of gravity. The grey lines indicate 887 ratios of SDI mixed / SDI mono of (from top to bottom) 1.4, 1.0, and 0.7. The top left diagram shows all data, all other diagrams display single species combinations.

891 Figure 3: Boxplot of $D E N S R=\frac{S D I_{1,2}}{\hat{S} D I_{1,2}}-1$ for all species mixtures (left) and all species associations containing Norway spruce (right). In both cases, DENSR significantly deviates

893 from 0 , i.e. $\beta_{0}=+0.165(* * *: p<0.001)$ and $\beta_{0}=+0.088(*: p<0.05)$. Note that one outlier 
894 close to $D E N S R=2$ (from the mixture beech-douglas) has been excluded from the display for

895 the sake of a more appropriate scaling.

896

897

898 Figure 4: Boxplots of $D E N S R=\frac{S D I_{1,2}}{\hat{S} D I_{1,2}}-1$ for all species associations represented in our 899 data. Numbers above the boxes indicate the expected deviation of DENSR from zero. In the 900 cases of spruce-larch and pine-beech these deviations are significant $\left(\beta_{0}=+0.291 * *\right.$, $901 p<0.01 ; \beta_{0}=+0.359^{* * *}, p<0.001$ ). Note that one outlier close to DENSR $=2$ (from the 902 mixture beech-douglas) has been excluded from the display for the sake of a more appropriate 903 scaling.

904

905

906 Figure 5: $D E N S R=\frac{S D I_{1,2}}{\hat{S} D I_{1,2}}-1$ plotted over stand age for all species associations (left) and all 907 associations containing Norway spruce (right). Grey circles represent a build of a triplet, grey

908 lines connect subsequent builds of one triplet. Black lines represent model predictions for 909 DENSR dependent on age, which are, however, not significant. Note that one outlier close to $910 D E N S R=2$ (from the mixture beech-douglas) has been excluded from the display in the left 911 diagram for the sake of a more appropriate scaling.

912

913

914 Figure 6: $\quad D E N S R=\frac{S D I_{1,2}}{\hat{S} D I_{1,2}}-1$ plotted over the standardized site index for all species 915 associations (left) and all associations containing Norway spruce (right). Grey circles 916 represent a build of a triplet, grey lines connect subsequent builds of one triplet. Black lines 
917 represent model predictions for DENSR dependent on age, which are, however, not 918 significant. Note that one outlier close to $D E N S R=2$ (from the mixture beech-douglas) has

919 been excluded from the display in the left diagram for the sake of a more appropriate scaling. 920

921

922

923

Figure 7: Self thinning in mixed and monospecific stands displayed for the species combinations where significant mixture effects were previously identified. For each build in each triplet we calculated a mean diameter $d_{q}$ for the mixed and a combination of the two monospecific stands, by weighting the species specific diameters with the species' area shares of the mixed stand. In the same way, we obtained a stem number $N$ per ha for the monospecific stands which represents a combination without mixture effects. The self thinning lines were obtained by fitting mixed linear $\log (N)$ - $\log \left(d_{q}\right)$-models (random effect on triplet level); they show significant positive deviations of the mixed stands in the same order 930 of magnitude as demonstrated before.

931

932

934

935

936
Table 1: Numbers of trials, plots and surveys which were used to compile triplets for the purpose of this study.

Table 2: Numbers of triplets and builds compiled from plots from different sources. The source "combined" means triplets and builds made up from both previously listed sources (permanent plot network, temporary plots). 
942 Table 3: Number of triplets and builds for the investigated species associations. A triplet is a

943 combination of three research plots (one mixed, two pure stands). A build is a combination of

944 given surveys of these plots inside a triplet. Thus, a triplet contains at least one, typically more

945 than one build.

946

947

948 Table 4: Overview of climate and location for all investigated species associations. The length

949 of the growing season is defined as the number of days, where the mean daily temperature

950 was at least $10^{\circ} \mathrm{C}$.

951

952

953 Table 5: Stand characteristics grouped by investigated species associations. Note that the

954 area-related stand parameters (stem number, basal area, volume, SDI) of the species in the

955 mixed stands refer to the whole stand area, not to the species' share of the area. The site

956 index was estimated by means of appropriate yield tables assembled by Schober (1975); for

957 the purpose of this study, we defined it as the height of the tree with the quadratic mean

958 diameter at stand age of 80 years from the yield table..

959

960

961 Table 6: Mean equivalence coefficients for converting the SDI from one species to the other.

962 The matrix shows, for all eight tree species included in this study, the equivalence coefficients

$963 \mathrm{e}_{1 \Rightarrow 2}=\mathrm{SDIMAX}_{2} /$ SDIMAX $_{1}$ for transforming the species-specific density of a species 1

964 (entry via the left column) to species 2 (read off via the upper line). A density of SDI= 900 in

965 a Norway spruce stand is equivalent to a density of SDI $=567$ in a European beech stand

$966 \quad\left(\mathrm{SDI}_{\text {E.be. }}=\mathrm{SDI}_{\mathrm{N} . \text { sp. }} \times \mathrm{e}_{1 \Rightarrow 2}\right)$ with $e_{1 \Rightarrow 2}=0.63$ 
968

969 Table 7: Fit results of all presented mixed linear models. The notation refers to Equation 12.

970 Significant fixed effect parameter estimates are printed in bold. Random effects with no entry

971 for their variance $\tau^{2}$ were not included in the final model due to AIC comparisons or were not

972 meaningful due to the data structure.

973

974 
975 Figures:

976
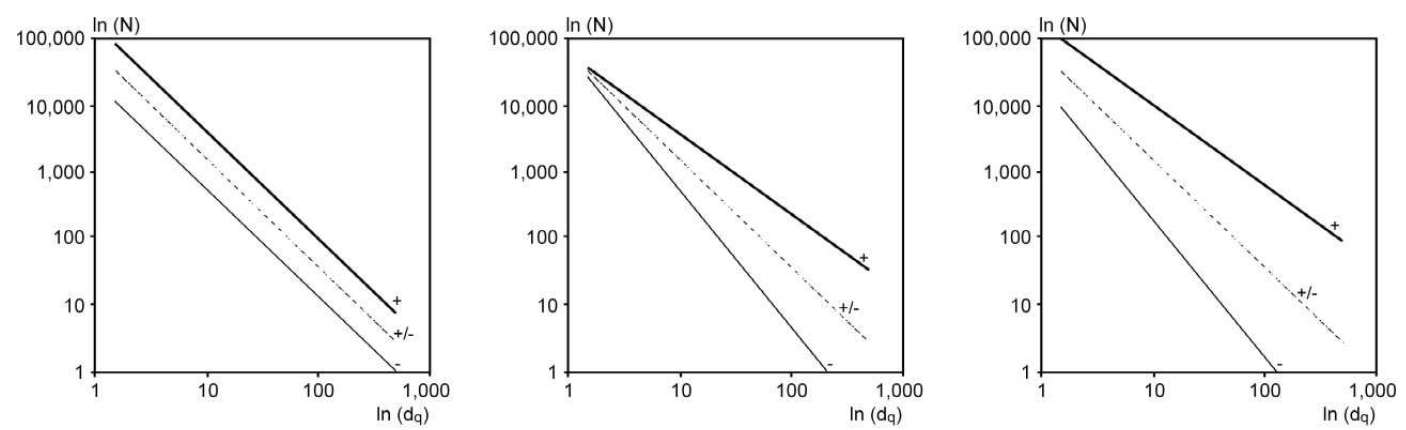

977

978

Figure 1

(b)

(c)

979

980 
981
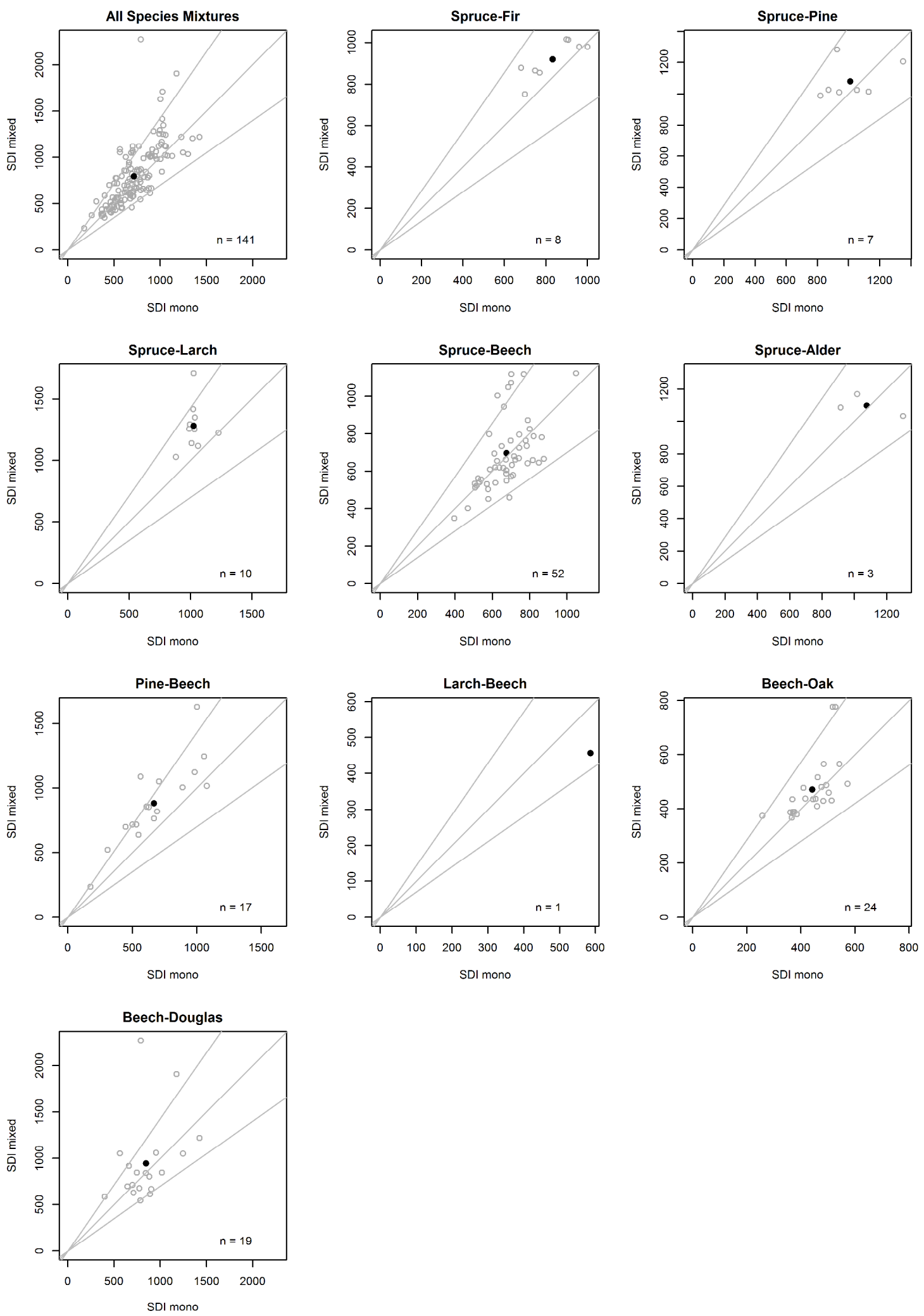

Figure 2 


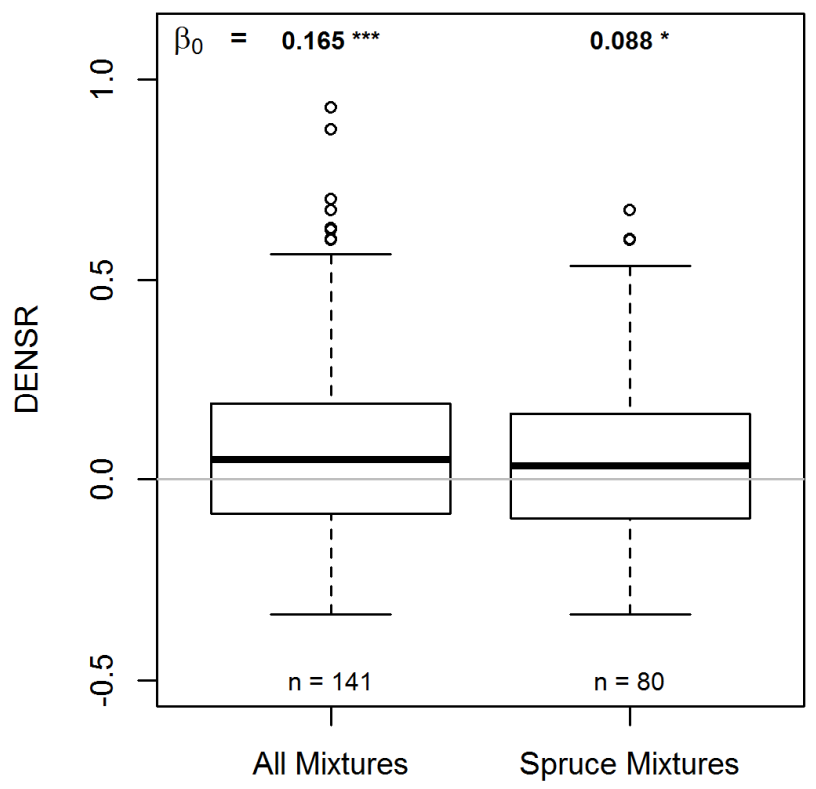

987

988

989

990

991

992

993

994

Figure 3

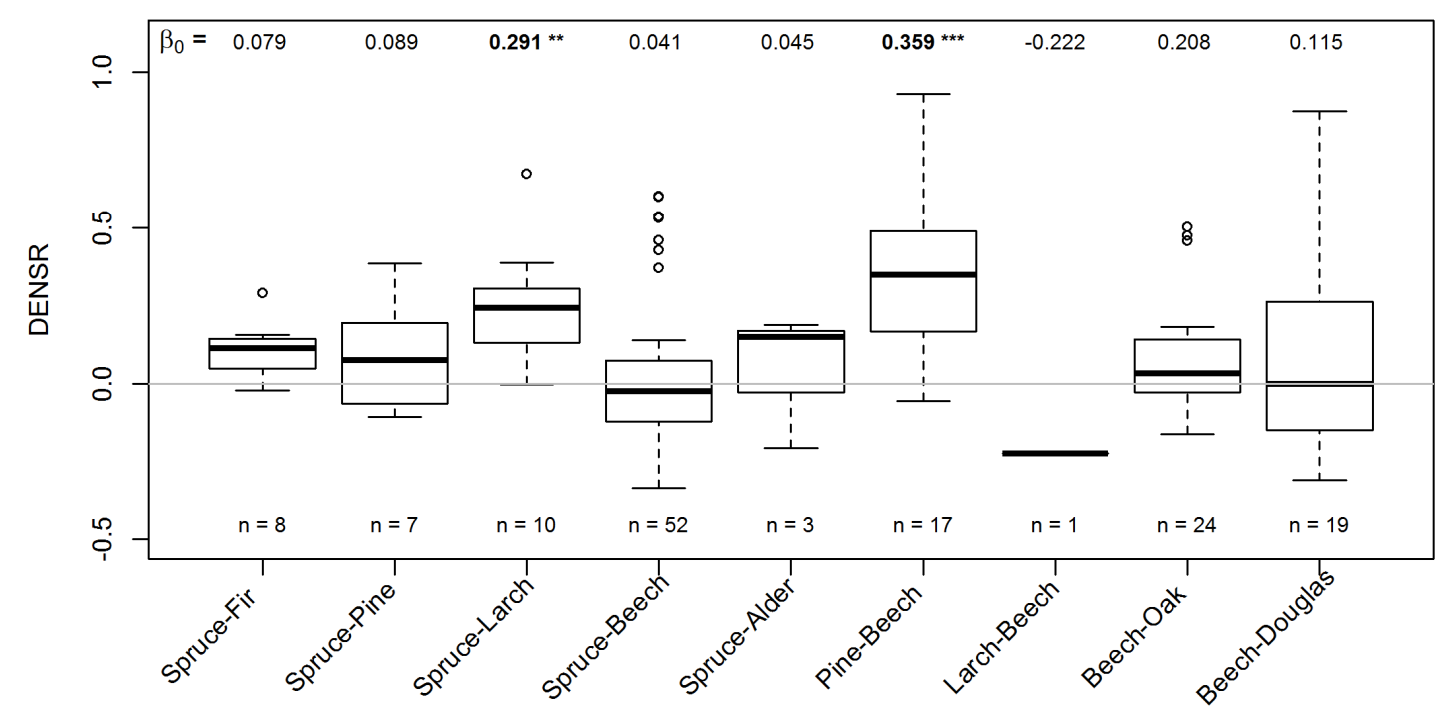

Figure 4 
995

996
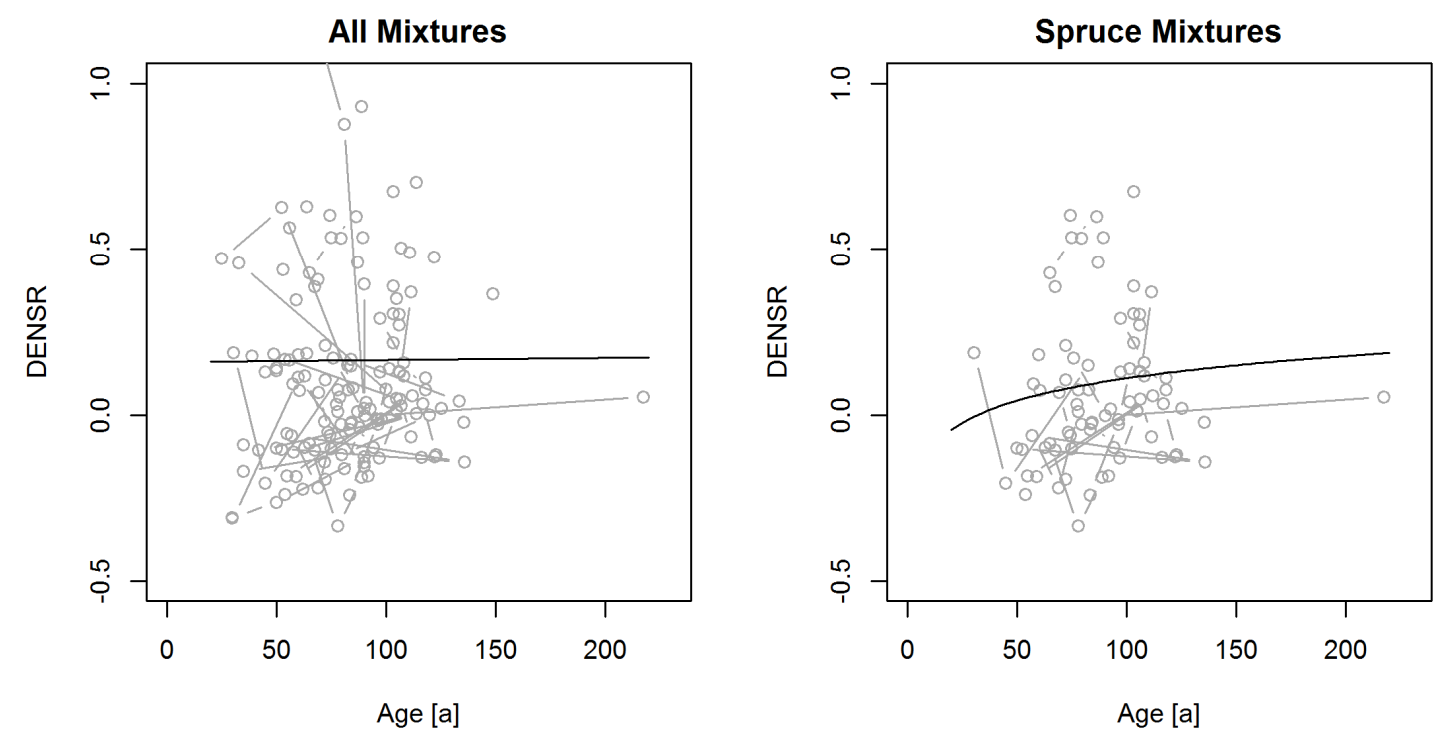

997

998

999

Figure 5

1000

1001
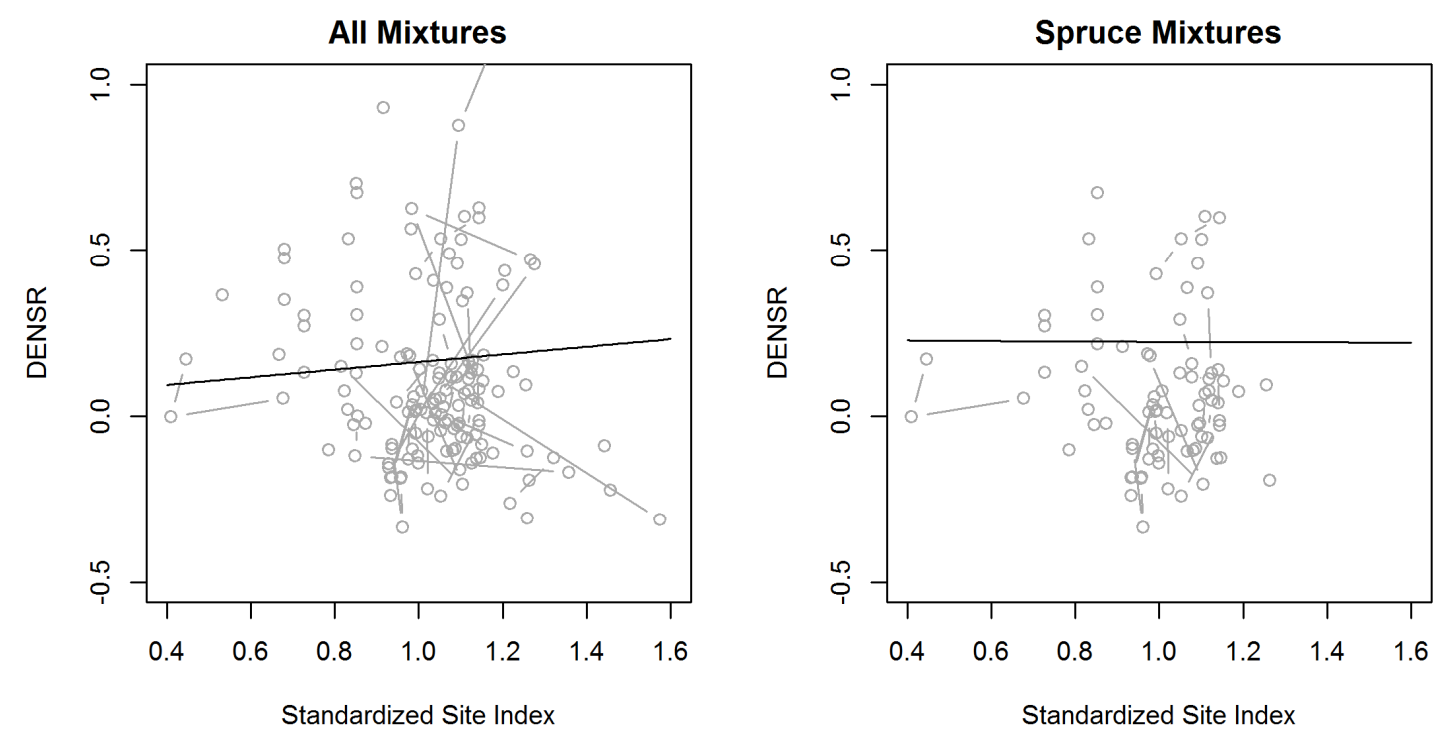

1002

1003

1004

Figure 6

1005

1006 

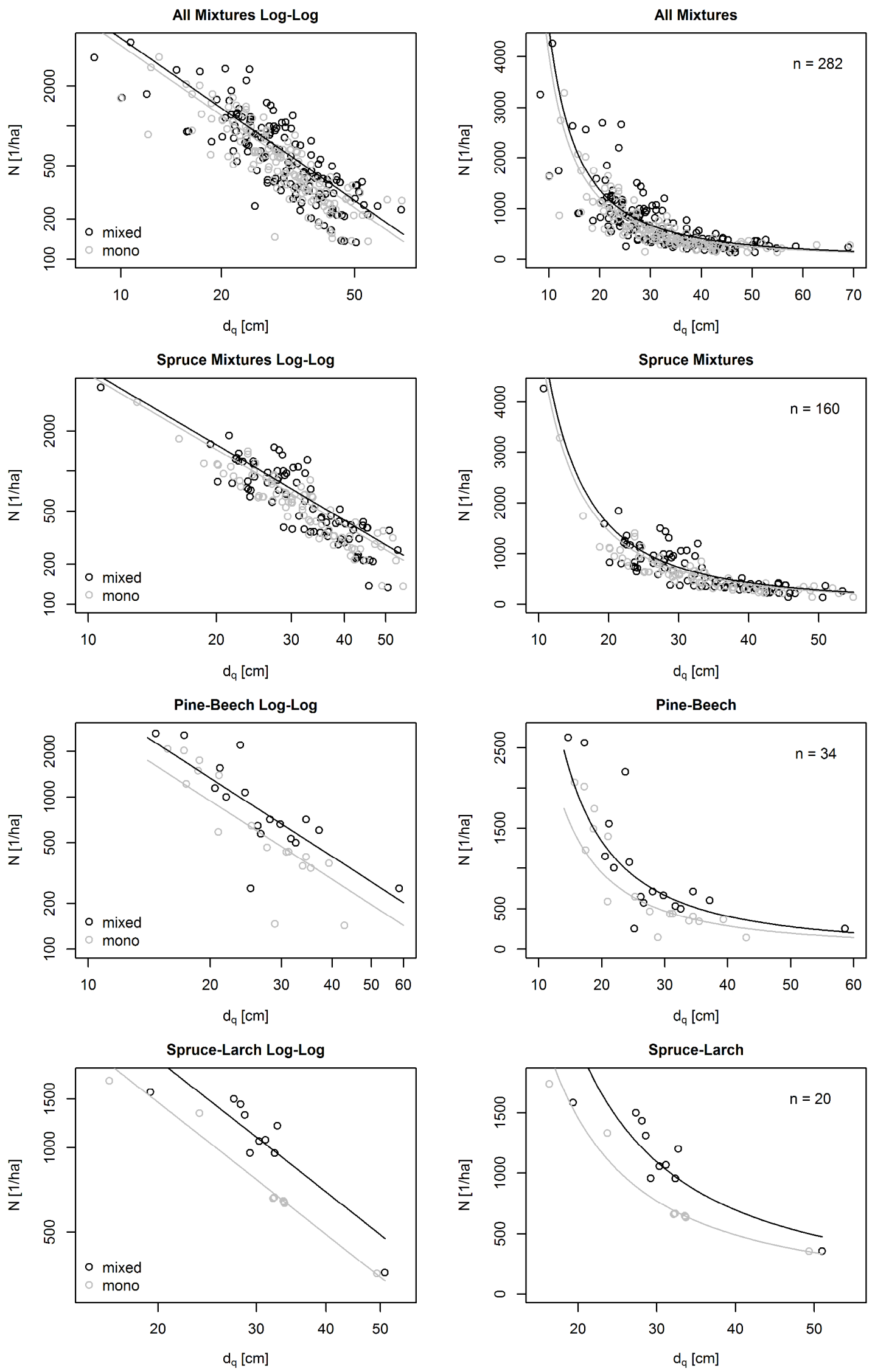

Figure 7 
Tables

1011

1012

1013

Table 1

1014

\begin{tabular}{lccc}
\hline Source & Trials & Plots & Surveys \\
\hline Permanent Plot Network & 29 & 60 & 217 \\
Temporary Plots & 37 & 156 & 156 \\
\hline Sum & 66 & 216 & 373 \\
\hline
\end{tabular}

1015

1016

1017

Table 2

1018

\begin{tabular}{lcc}
\hline Source & Triplets & Builds \\
\hline Permanent Plot Network & 26 & 87 \\
Temporary Plots & 37 & 52 \\
Combined & 2 & 2 \\
\hline Sum & 65 & 141 \\
\hline
\end{tabular}

1019

1020

1021

Table 3

1022

\begin{tabular}{lcccccccccc}
\hline & $\begin{array}{c}\text { Spruce- } \\
\text { Fir }\end{array}$ & $\begin{array}{c}\text { Spruce- } \\
\text { Pine }\end{array}$ & $\begin{array}{c}\text { Spruce- } \\
\text { Larch }\end{array}$ & $\begin{array}{c}\text { Spruce- } \\
\text { Beech }\end{array}$ & $\begin{array}{c}\text { Spruce- } \\
\text { Alder }\end{array}$ & $\begin{array}{c}\text { Pine- } \\
\text { Beech }\end{array}$ & $\begin{array}{c}\text { Larch- } \\
\text { Beech }\end{array}$ & $\begin{array}{c}\text { Beech- } \\
\text { Oak }\end{array}$ & $\begin{array}{c}\text { Beech- } \\
\text { Douglas }\end{array}$ & $\begin{array}{c}\text { Sum } \\
\text { Bam }\end{array}$ \\
\hline Triplets & 3 & 7 & 8 & 15 & 1 & 17 & 1 & 5 & 8 & 65 \\
Builds & 8 & 7 & 10 & 52 & 3 & 17 & 1 & 24 & 19 & 141 \\
\hline
\end{tabular}

1023

1024 
Table 4

\begin{tabular}{|c|c|c|c|c|c|c|c|c|c|c|c|c|c|c|c|c|c|c|c|c|c|c|c|c|}
\hline \multirow[b]{2}{*}{ Species Association } & \multicolumn{3}{|c|}{$\begin{array}{c}\text { Mean Annual } \\
\text { Temperature }\left[{ }^{\circ}\right]\end{array}$} & \multicolumn{3}{|c|}{$\begin{array}{c}\text { Annual Precipitation } \\
{[\mathrm{mm}]}\end{array}$} & \multicolumn{3}{|c|}{$\begin{array}{l}\text { Height Above } \\
\text { Sea Level [m] }\end{array}$} & \multicolumn{3}{|c|}{\begin{tabular}{|c|} 
Length of the \\
Growing Season $[\mathrm{d} / \mathrm{a}]$
\end{tabular}} & \multicolumn{3}{|c|}{ Longitude East $\left[^{\circ}\right]$} & \multicolumn{3}{|c|}{ Latitude North $\left[^{\circ}\right]$} & \multicolumn{3}{|c|}{ Exposition $\left[{ }^{\circ}\right]$} & \multicolumn{3}{|c|}{ Slope $\left[{ }^{\circ}\right]$} \\
\hline & $\min$ & mean & $\max$ & $\min$ & mean & $\max$ & $\min$ & mean & $\max$ & $\min$ & mean & $\max$ & $\min$ & mean & $\max$ & $\min$ & mean & $\max$ & $\min$ & mean & $\max$ & $\min$ & mean & $\mathrm{ma}$ \\
\hline Spruce-Fir & 4 & 5.3 & 7.5 & 1170 & 1790 & 2400 & 650 & 1020 & 1280 & 165 & 176 & 190 & 10.144 & 11.078 & 11.720 & 47.398 & 47.665 & 47.941 & 0 & 90 & 180 & 0 & 10 & 1 \\
\hline Spruce-Pine & 6.7 & 7.9 & 9.3 & 625 & 711 & 810 & 250 & 401 & 550 & 188 & 197 & 201 & 9.079 & 11.012 & 12.318 & 48.567 & 49.292 & 50.146 & 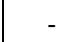 & - & & 0 & 0 & ) \\
\hline Spruce-Larch & 5.5 & 7.3 & 10.4 & 552 & 917 & 1100 & 1245 & 1503 & 1715 & 151 & 157 & 167 & 10.779 & 12.686 & 13.639 & 46.590 & 46.928 & 47.097 & 45 & 90 & 180 & 22 & 24 & 2 \\
\hline $\mathrm{S}$ & 5.5 & 1 & 8.7 & 620 & 1018 & 1350 & 340 & 6 & 785 & 181 & 1 & 98 & 9 & 11.807 & 99 & 7 & 6 & 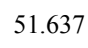 & 90 & 48 & 315 & 0 & 5 & 5 \\
\hline Spruce-Alder & 8.4 & 8.4 & 8.4 & 1003 & 1003 & 1003 & 585 & 585 & 585 & 193 & 193 & 193 & 11.036 & 11.036 & 11.036 & 47.938 & 47.938 & 47.938 & - & - & & 0 & 0 & 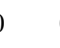 \\
\hline Pine-Beech & 6 & 8.2 & 10.5 & 560 & 760 & 1175 & 20 & 325 & 1290 & 179 & 196 & 213 & -3.172 & 12.992 & 23.351 & 41.895 & 50.236 & 56.153 & 0 & 80 & 315 & 0 & 4 & 2 \\
\hline Larch- & 6.5 & 7.3 & 7.7 & 900 & 1000 & 1200 & 380 & 405 & 435 & 194 & 195 & 196 & 9. & 9.834 & 10.519 & 49.852 & 50.002 & 50.197 & 0 & 135 & 225 & 7 & 10 & 1 \\
\hline Beech-Oak & 7 & 7.4 & 8.5 & 690 & 936 & 1120 & 340 & 416 & 470 & 193 & 195 & 199 & 9.336 & 9.604 & 10.519 & 49.685 & 49.865 & 49.992 & 0 & 87 & 225 & 0 & 4 & + \\
\hline Beech-Douglas & 7.5 & 8.3 & 9.4 & 651 & 826 & 927 & 330 & 473 & 588 & 192 & 195 & 198 & 6.743 & 9.871 & 11.909 & 48.121 & 49.179 & 50.173 & 125 & 125 & 125 & 0 & 2 & 2 \\
\hline
\end{tabular}


Table 5

\begin{tabular}{|c|c|c|c|c|c|c|c|c|c|c|c|c|c|c|c|c|c|c|c|c|c|c|c|c|c|c|}
\hline $\begin{array}{c}\text { Species } \\
\text { Asssociation }\end{array}$ & $\begin{array}{c}\text { Mixed } \\
/ \\
\text { Mono } \\
\end{array}$ & Species & $\min$ & \multicolumn{2}{|c|}{ Age [a] } & \multicolumn{3}{|c|}{$\begin{array}{c}\text { Stem Number } \\
{[1 / \mathrm{ha}]}\end{array}$} & \multicolumn{3}{|c|}{$\begin{array}{c}\text { Basal Area } \\
{\left[\mathbf{m}^{2} / \mathbf{h a}\right]}\end{array}$} & \multicolumn{3}{|c|}{$\begin{array}{l}\text { Volume } \\
{\left[\mathbf{m}^{3} / \mathbf{h a}\right]}\end{array}$} & \multicolumn{3}{|c|}{$\begin{array}{l}\text { Quadratic Mean } \\
\text { Diameter } \\
\text { [cm] }\end{array}$} & \multicolumn{3}{|c|}{$\begin{array}{l}\text { Height of the quad. } \\
\text { mean diameter } \\
{[\mathrm{m}]}\end{array}$} & \multicolumn{3}{|c|}{$\begin{array}{l}\text { Site Index } \\
\text { [m] }\end{array}$} & \multicolumn{3}{|c|}{ SDI [1/ha] } \\
\hline Spruce-Fir & mixed & Spruce & 85 & 102 & 122 & 51 & 209 & 410 & 8.7 & 31.5 & 44.9 & 134 & 461 & 674 & 37.0 & 44.6 & 52.1 & 31.9 & 34.2 & 38.7 & 26.4 & 30.5 & 33.8 & 139 & 512 & 769 \\
\hline (3 triplets & & Fir & 113 & 123 & 134 & 75 & 179 & 352 & 15.0 & 24.6 & 38.9 & 202 & 346 & 557 & 36.4 & 43.9 & 55.7 & 27.7 & 31.7 & 36.6 & 19.4 & 23.0 & 26.2 & 247 & 406 & 662 \\
\hline \multirow[t]{2}{*}{8 builds) } & mono & Spruce & 85 & 106 & 141 & 313 & 471 & 656 & 51.4 & 60.3 & 74.8 & 855 & 929 & 1118 & 33.9 & 41.8 & 50.5 & 31.6 & 35.0 & 38.8 & 25.2 & 31.0 & 33.9 & 824 & 1025 & 1221 \\
\hline & & Fir & 110 & 121 & 130 & 195 & 225 & 255 & 36.5 & 42.6 & 45.1 & 498 & 595 & 637 & 42.6 & 49.3 & 54.2 & 31.6 & 33.2 & 34.2 & 24.3 & 24.7 & 25.0 & 601 & 662 & 690 \\
\hline \multirow{4}{*}{$\begin{array}{l}\text { Spruce-Pine } \\
\text { (7 triplets } \\
7 \text { builds) }\end{array}$} & mixed & Spruce & 60 & 76 & 93 & 608 & 835 & 1338 & 23.0 & 29.1 & 38.7 & 216 & 341 & 521 & 17.6 & 21.5 & 26.9 & 18.4 & 22.3 & 26.7 & 17.9 & 23.4 & 27.8 & 524 & 627 & 769 \\
\hline & & Pine & 60 & 75 & 85 & 239 & 350 & 508 & 17.9 & 23.3 & 26.7 & 231 & 283 & 354 & 25.2 & 30.0 & 36.2 & 23.3 & 26.8 & 31.0 & 22.8 & 27.9 & 32.0 & 336 & 453 & 515 \\
\hline & mono & Spruce & 60 & 74 & 93 & 635 & 885 & 1304 & 41.6 & 49.9 & 60.3 & 475 & 650 & 856 & 19.4 & 27.4 & 33.1 & 22.3 & 26.2 & 29.7 & 23.8 & 28.0 & 32.4 & 855 & 974 & 1098 \\
\hline & & Pine & 60 & 70 & 85 & 472 & 926 & 1558 & 38.4 & 45.9 & 60.3 & 397 & 519 & 721 & 25.6 & 29.1 & 33.7 & 22.4 & 25.6 & 29.2 & 25.2 & 27.6 & 32.6 & 737 & 1176 & 2230 \\
\hline \multirow{4}{*}{$\begin{array}{c}\text { Spruce-Larch } \\
\text { (8 triplets } \\
10 \text { builds) }\end{array}$} & mixed & Spruce & 64 & 100 & 232 & 212 & 644 & 989 & 7.9 & 23.4 & 36.7 & 46 & 230 & 491 & 11.8 & 23.0 & 46.9 & 8.0 & 17.4 & 29.9 & 10.6 & 16.0 & 23.5 & 216 & 485 & 709 \\
\hline & & Larch & 65 & 115 & 241 & 146 & 498 & 778 & 26.2 & 44.5 & 58.5 & 186 & 623 & 951 & 20.7 & 35.4 & 56.2 & 15.5 & 28.5 & 34.7 & 17.5 & 25.9 & 30.5 & 536 & 794 & 1004 \\
\hline & mono & Spruce & 78 & 114 & 222 & 355 & 771 & 1908 & 38.2 & 51.3 & 61.9 & 239 & 695 & 935 & 16.0 & 31.8 & 47.1 & 13.2 & 25.5 & 29.4 & 12.4 & 21.6 & 25.8 & 904 & 961 & 1126 \\
\hline & & Lartir & 00 & 110 & 213 & 356 & 817 & 1622 & 35.3 & 58.0 & 76.3 & 241 & 708 & 938 & 16.6 & 32.3 & 52.2 & 15.0 & 26.6 & 30.0 & 15.7 & 24.5 & 21.0 & 841 & 1073 & 1347 \\
\hline \multirow{4}{*}{$\begin{array}{l}\text { Spruce-Beech } \\
\text { (15 triplets } \\
52 \text { builds) }\end{array}$} & mixed & Spruce & 46 & 82 & 136 & 11 & 200 & 526 & 2.4 & 21.6 & 35.6 & 36 & 311 & 581 & 22.6 & 40.7 & 58.4 & 19.3 & 31.5 & 40.9 & 25.5 & 31.9 & 37.0 & 36 & 368 & 639 \\
\hline & & Beech & 50 & 91 & 136 & 122 & 340 & 937 & 5.3 & 36.5 & 49.0 & 39 & 236 & 509 & 15.0 & 26.9 & 49.3 & 15.9 & 25.9 & 35.3 & 16.1 & 24.1 & 32.7 & 133 & 327 & 658 \\
\hline & mono & Spruce & 46 & 81 & 136 & 58 & 519 & 1287 & 14.4 & 43.4 & 63.2 & 218 & 629 & 1093 & 18.7 & 36.3 & 61.0 & 17.8 & 31.1 & 40.7 & 25.2 & 31.9 & 38.3 & 217 & 779 & 1128 \\
\hline & & Beech & 50 & 90 & 136 & 154 & 553 & 1325 & 22.2 & 29.5 & 50.4 & 178 & 420 & 716 & 15.6 & 28.6 & 53.5 & 16.8 & 26.4 & 38.6 & 18.6 & 25.0 & 33.1 & 374 & 577 & 1029 \\
\hline \multirow{4}{*}{$\begin{array}{c}\text { Spruce-Alder } \\
\text { (1 triplet } \\
3 \text { builds) }\end{array}$} & mixed & Spruce & 25 & 52 & 85 & 322 & 1129 & 2378 & 19.8 & 26.4 & 31.2 & 99 & 264 & 407 & 10.3 & 22.8 & 35.2 & 10.8 & 19.3 & 27.3 & 26.3 & 30.6 & 33.8 & 558 & 575 & 596 \\
\hline & & Alder & 27 & 52 & 85 & 407 & 955 & 1888 & 18.1 & 23.9 & 33.2 & 94 & 236 & 470 & 11.1 & 21.5 & 32.2 & 12.6 & 20.6 & 28.7 & 21.9 & 25.3 & 28.1 & 438 & 521 & 611 \\
\hline & mono & Spruce & 28 & 51 & 80 & 1197 & 2532 & 5000 & 31.6 & 49.5 & 64.0 & 141 & 495 & 792 & 9.0 & 19.0 & 26.2 & 10.3 & 18.7 & 24.7 & 24.7 & 29.2 & 33.5 & 970 & 1131 & 1291 \\
\hline & & Alder & 33 & 54 & 85 & 498 & 1170 & 1594 & 32.5 & 44.9 & 55.3 & 254 & 483 & 607 & 17.0 & 26.4 & 34.9 & 17.1 & 22.5 & 26.7 & 25.3 & 27.0 & 29.5 & 851 & 1114 & 1632 \\
\hline
\end{tabular}


Table 5 cont

\begin{tabular}{|c|c|c|c|c|c|c|c|c|c|c|c|c|c|c|c|c|c|c|c|c|c|c|c|c|c|c|}
\hline $\begin{array}{c}\text { Species } \\
\text { Asssociation }\end{array}$ & $\begin{array}{c}\text { Mixed } \\
\text { I } \\
\text { Mono } \\
\end{array}$ & Species & $\min$ & \multicolumn{2}{|c|}{ Age [a] } & \multicolumn{3}{|c|}{$\begin{array}{c}\text { Stem Number } \\
{[1 / \mathrm{ha}]}\end{array}$} & \multicolumn{3}{|c|}{$\begin{array}{c}\text { Basal Area } \\
{\left[\mathbf{m}^{2} / \mathbf{h a}\right]}\end{array}$} & \multicolumn{3}{|c|}{$\begin{array}{l}\text { Volume } \\
{\left[\mathbf{m}^{3} / \mathbf{h a}\right]}\end{array}$} & \multicolumn{3}{|c|}{$\begin{array}{l}\text { Quadratic Mean } \\
\text { Diameter } \\
\text { [cm] }\end{array}$} & \multicolumn{3}{|c|}{$\begin{array}{l}\text { Height of the quad. } \\
\text { mean diameter } \\
\text { [m] }\end{array}$} & \multicolumn{3}{|c|}{$\begin{array}{l}\text { Site Index } \\
\quad[\mathrm{m}]\end{array}$} & \multicolumn{3}{|c|}{ SDI [1/ha] } \\
\hline Pine-Beech & mixed & & 39 & 7 & 149 & 50 & 425 & 1529 & 7 & 2 & 43.5 & 78 & 293 & 658 & .6 & 32.6 & 70.1 & 17.3 & 24.7 & 33.2 & 16.4 & 27.4 & 33.9 & 143 & 484 & 838 \\
\hline (17 triplets & & Beech & 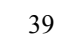 & 7 & 149 & 125 & 611 & 1733 & 4.2 & 17.9 & 36.8 & 45 & 208 & 392 & 11.2 & 22.0 & 29.4 & 12.7 & 22.6 & 30.0 & 11.8 & 26.4 & 35.0 & 93 & 398 & 884 \\
\hline \multirow[t]{2}{*}{17 builds) } & mono & Pine & 39 & 74 & 149 & 82 & 747 & 2054 & 8.3 & 35.5 & 53.6 & 97 & 383 & 671 & 16.8 & 29.2 & 45.5 & 16.0 & 24.0 & 33.9 & 14.7 & 26.7 & 33.3 & 155 & 713 & 1188 \\
\hline & & Beech & 39 & 74 & 149 & 220 & 962 & 2542 & 10.7 & 29.8 & 43.0 & 135 & 360 & 577 & 12.7 & 24.0 & 40.4 & 13.7 & 23.8 & 33.0 & 17.4 & 27.5 & 35.9 & 219 & 640 & 1034 \\
\hline \multirow{4}{*}{$\begin{array}{c}\text { Larch-Beech } \\
\text { (1 triplet } \\
1 \text { build })\end{array}$} & mixed & Larch & 66 & 66 & 66 & 98 & 98 & 98 & 7.9 & 7.9 & 7.9 & 91 & 91 & 91 & 32.1 & 32.1 & 32.1 & 25.8 & 25.8 & 25.8 & 28.4 & 28.4 & 28.4 & 146 & 146 & 146 \\
\hline & & 2 & 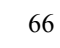 & 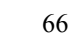 & $6 c$ & 293 & 293 & 293 & 15.4 & 15.4 & 15.4 & 182 & 182 & 182 & 25.9 & 25.9 & 25.9 & 20.2 & 23.2 & 23.2 & 21.0 & 21.0 & - & 310 & 310 & 310 \\
\hline & mono & 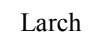 & 5 & 55 & 55 & 498 & 498 & 498 & 38.7 & 38.7 & 38.7 & 549 & 549 & 549 & 31.4 & 31.4 & 31.4 & 30.7 & 30.7 & 30.7 & 37.2 & 37.2 & 37.2 & 718 & 718 & 718 \\
\hline & & Beech & 69 & 69 & 69 & 572 & 572 & 572 & 26.1 & 26.1 & 26.1 & 332 & 332 & 332 & 24.1 & 24.1 & 24.1 & 25.1 & 25.1 & 25.1 & 28.3 & 28.3 & 28.3 & 539 & 539 & 539 \\
\hline \multirow{4}{*}{$\begin{array}{c}\text { Beech-Oak } \\
\text { (5 triplets } \\
24 \text { builds) }\end{array}$} & mixed & Beech & 33 & 82 & 116 & 50 & 211 & 651 & 6.4 & 11.8 & 17.7 & 36 & 161 & 257 & 11.1 & 31.9 & 53.0 & 13.2 & 25.6 & 34. & 13.3 & 26.2 & 31.9 & 133 & 224 & 319 \\
\hline & & & (3) & 82 & 116 & 00 & 276 & 983 & 6.2 & 12.2 & 27.2 & 33 & 158 & 365 & 9.2 & 27.0 & 42.4 & 11.5 & 24.5 & 52.2 & 21.0 & 2. & 27.5 & 139 & 246 & 524 \\
\hline & mono & Beech & 33 & 82 & 135 & 128 & 352 & 660 & 9.8 & 25.5 & 35.3 & 68 & 385 & 661 & 14.0 & 33.3 & 51.6 & 15.4 & 28.2 & 35.9 & 18.7 & 29.1 & 35.1 & 260 & 469 & 586 \\
\hline & & Oak & 33 & 84 & 132 & 145 & 415 & 1178 & 8.8 & 21.3 & 31.3 & 47 & 283 & 482 & 10.4 & 28.8 & 42.2 & 11.9 & 25. & 32 & 21.9 & 24.9 & 27.8 & 254 & 415 & 562 \\
\hline \multirow{4}{*}{$\begin{array}{c}\text { Beech- } \\
\text { Douglas } \\
\text { (8 triplets }\end{array}$} & mixed & Deren & (2) & 0 & 120 & 27 & 622 & $1 / 30$ & 1.1 & 17.2 & 40.3 & 18 & 220 & 485 & 1.0 & 22.6 & 43.4 & 7.5 & 23.3 & 33.9 & 15.7 & 31.2 & 40.4 & 65 & 372 & 900 \\
\hline & & Douglas & 25 & 63 & 120 & 35 & 385 & 1894 & 11.1 & 34.2 & 83.2 & 34 & 490 & 1184 & 9.1 & 50.4 & 83.2 & 8.4 & 33.3 & 48.6 & 30.4 & 41.2 & 52.0 & 221 & 573 & 1495 \\
\hline & mono & Beech & 25 & 64 & 120 & 172 & 1079 & 3333 & 8.0 & 31.9 & 47.7 & 35 & 421 & 811 & 8.7 & 26.3 & 53.6 & 10.9 & 24.3 & 39.2 & 23.3 & 32.0 & 43.3 & 243 & 670 & 1146 \\
\hline & & Douglas & 25 & 65 & 120 & 182 & 660 & 2157 & 22.3 & 64.1 & 113.7 & 110 & 989 & 2071 & 11.5 & 43.0 & 74.0 & 11.8 & 33.7 & 50.5 & 30.7 & 41.1 & 52.9 & 620 & 1058 & 1665 \\
\hline
\end{tabular}


Table 6

\begin{tabular}{lcccccccc}
\hline & $\begin{array}{c}\text { Norway } \\
\text { spruce }\end{array}$ & silver fir & Scots pine & $\begin{array}{c}\text { European } \\
\text { larch }\end{array}$ & $\begin{array}{c}\text { European } \\
\text { beech }\end{array}$ & sessile oak & $\begin{array}{c}\text { Douglas- } \\
\text { fir }\end{array}$ & \begin{tabular}{c} 
black alder \\
\hline Norway spruce
\end{tabular} \\
\hline 1.00 & 0.78 & 0.85 & 1.21 & 0.63 & 0.44 & 1.13 & 0.99 \\
silver fir & 1.29 & 1.00 & 1.09 & 1.56 & 0.81 & 0.56 & 1.45 & 1.27 \\
Scots pine & 1.18 & 0.92 & 1.00 & 1.43 & 0.74 & 0.51 & 1.33 & 1.16 \\
European larch & 0.83 & 0.64 & 0.70 & 1.00 & 0.52 & 0.36 & 0.93 & 0.82 \\
European beech & 1.60 & 1.24 & 1.35 & 1.93 & 1.00 & 0.70 & 1.80 & 1.58 \\
sessile oak & 2.29 & 1.78 & 1.94 & 2.77 & 1.43 & 1.00 & 2.58 & 2.26 \\
Douglas-fir & 0.89 & 0.69 & 0.75 & 1.07 & 0.56 & 0.39 & 1.00 & 0.88 \\
black alder & 1.01 & 0.79 & 0.86 & 1.23 & 0.63 & 0.44 & 1.14 & 1.00 \\
\hline
\end{tabular}




\begin{tabular}{|c|c|c|c|c|c|c|c|c|c|c|c|c|}
\hline \multirow[b]{2}{*}{ Model } & \multicolumn{5}{|c|}{ Fixed Effects } & \multicolumn{7}{|c|}{ Random Effects } \\
\hline & $\begin{array}{c}\text { Fixed } \\
\text { Effect } \\
\text { Parameter }\end{array}$ & $\begin{array}{c}\text { Predictor } \\
\text { Variable X }\end{array}$ & Estimate & Std. Error & $\mathbf{p}$ & $\begin{array}{c}\text { Triplet } \\
\tau_{1}^{2}\end{array}$ & $\begin{array}{c}\text { First pure } \\
\text { stand: } \\
\text { Trial } \\
\tau_{2}^{i}\end{array}$ & $\begin{array}{c}\text { First pure } \\
\text { stand: } \\
\text { Plot in } \\
\text { Trial } \\
\tau_{9}^{2}\end{array}$ & $\begin{array}{c}\text { Second } \\
\text { pure } \\
\text { stand: } \\
\text { Trial } \\
\boldsymbol{\pi}_{4}^{2} \\
\end{array}$ & $\begin{array}{l}\text { Second } \\
\text { pure } \\
\text { stand: } \\
\text { Plot in } \\
\text { Trial } \\
\tau_{5}^{2}\end{array}$ & $\begin{array}{c}\text { Mixed } \\
\text { stand: } \\
\text { Trial } \\
\tau_{\epsilon}^{2}\end{array}$ & $\begin{array}{c}\text { Mixed } \\
\text { stand: } \\
\text { Plot in } \\
\text { Trial } \\
\tau_{7}^{2} \\
\end{array}$ \\
\hline $\begin{array}{l}\text { All Mixtures \#1 } \\
(\mathrm{n}=141)\end{array}$ & $\beta_{2}$ & - & 0.1650 & 0.0429 & 0.0003 & - & 0.0000 & 0.0540 & - & - & 0.0321 & 0.0167 \\
\hline $\begin{array}{l}\text { Spruce Mixtures \#1 } \\
\quad(\mathrm{n}=80)\end{array}$ & $\beta_{0}$ & - & 0.0877 & 0.0390 & 0.0337 & - & - & - & - & - & 0.0195 & 0.0155 \\
\hline $\begin{array}{l}\text { Spruce-Fir } \\
(\mathrm{n}=8)\end{array}$ & $\beta_{2}$ & - & 0.0786 & 0.0738 & 0.4830 & - & - & - & - & - & 0.0093 & - \\
\hline $\begin{array}{l}\text { Spruce-Pine } \\
\quad(\mathrm{n}=7)\end{array}$ & B. & - & 0.0889 & 0.0686 & 0.2430 & - & - & - & - & - & - & - \\
\hline $\begin{array}{l}\text { Spruce-Larch } \\
\quad(\mathrm{n}=10)\end{array}$ & $\beta_{2}$ & - & 0.2908 & 0.0656 & 0.0028 & 0.0277 & - & - & - & - & - & - \\
\hline $\begin{array}{l}\text { Spruce-Beech } \\
\quad(\mathrm{n}=52)\end{array}$ & $\beta_{2}$ & - & 0.0412 & 0.0639 & 0.5330 & - & - & - & - & - & 0.0156 & - \\
\hline $\begin{array}{l}\text { Spruce-Alder } \\
\quad(\mathrm{n}=3)\end{array}$ & $\beta$ & - & 0.0446 & 0.1251 & 0.7560 & - & - & - & - & - & - & - \\
\hline $\begin{array}{l}\text { Pine-Beech } \\
(\mathrm{n}=17)\end{array}$ & $B_{2}$ & - & 0.3594 & 0.0606 & 0.0000 & - & - & - & - & - & - & - \\
\hline $\begin{array}{l}\text { Beech-Oak } \\
\quad(\mathrm{n}=24)\end{array}$ & $\beta_{2}$ & - & 0.2085 & 0.1085 & 0.1320 & 0.0523 & - & - & - & - & - & - \\
\hline $\begin{array}{l}\text { Beech-Douglas } \\
\quad(\mathrm{n}=19)\end{array}$ & $B_{2}$ & - & 0.1146 & 0.1500 & 0.4670 & 0.0920 & - & - & - & - & - & - \\
\hline \multirow[t]{2}{*}{$\begin{array}{l}\text { All Mixtures \#2 } \\
\quad(\mathrm{n}=141)\end{array}$} & $\beta$ & - & 0.1602 & 0.0637 & 0.0133 & - & 0.0000 & 0.0545 & - & - & 0.0322 & 0.0165 \\
\hline & $\beta_{2}$ & Age [a] & 0.0001 & 0.0006 & 0.9198 & & & & & & & \\
\hline \multirow[t]{2}{*}{$\begin{array}{l}\text { Spruce Mixtures \#2 } \\
\qquad(\mathrm{n}=80)\end{array}$} & $B_{0}$ & - & -0.3326 & 0.2696 & 0.2210 & & & & & & 0.0168 & 0.0172 \\
\hline & $\mathrm{B}_{2}$ & $\ln ($ Age $)$ & 0.0964 & 0.0610 & 0.1180 & & & & & & & \\
\hline \multirow[t]{2}{*}{$\begin{array}{l}\text { All Mixtures \#3 } \\
\quad(\mathrm{n}=141)\end{array}$} & $\beta_{2}$ & - & 0.0489 & 0.1644 & 0.7670 & - & 0.0000 & 0.0573 & - & - & 0.0337 & 0.0160 \\
\hline & $\rho_{2}$ & $\begin{array}{l}\text { Standardized } \\
\text { Site Index }\end{array}$ & 0.1145 & 0.1564 & 0.4660 & & & & & & & \\
\hline \multirow[t]{2}{*}{$\begin{array}{l}\text { Spruce Mixtures \#3 } \\
\qquad(\mathrm{n}=80)\end{array}$} & $\beta_{0}$ & - & 0.2237 & 0.1844 & 0.2320 & - & - & - & - & - & 0.0212 & 0.0137 \\
\hline & $h_{\mathrm{s}}$ & $\begin{array}{l}\text { Standardized } \\
\text { Site Index }\end{array}$ & -0.0047 & 0.0061 & 0.4500 & & & & & & & \\
\hline
\end{tabular}

3 